\title{
The carbon budget of terrestrial ecosystems in East Asia over the last two decades
}

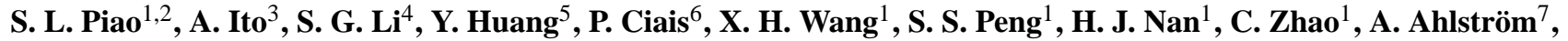 \\ R. J. Andres ${ }^{8}$, F. Chevallier ${ }^{6}$, J. Y. Fang ${ }^{1,5}$, J. Hartmann ${ }^{9}$, C. Huntingford ${ }^{10}$, S. Jeong ${ }^{11}$, S. Levis ${ }^{12}$, P. E. Levy ${ }^{13}$, \\ J. S. Li ${ }^{14}$, M. R. Lomas $^{15}$, J. F. Mao ${ }^{8}$, E. Mayorga ${ }^{16}$, A. Mohammat ${ }^{17}$, H. Muraoka ${ }^{18}$, C. H. Peng ${ }^{19,20}$, P. Peylin ${ }^{6}$, \\ B. Poulter ${ }^{6}$, Z. H. Shen ${ }^{1}$, X. Shi ${ }^{8}$, S. Sitch ${ }^{21}$, S. Tao ${ }^{1}$, H. Q. Tian ${ }^{22}$, X. P. Wu ${ }^{14}$, M. Xu ${ }^{4}$, G. R. Yu ${ }^{4}$, N. Viovy ${ }^{6}$, \\ S. Zaehle ${ }^{23}$, N. Zeng ${ }^{24}$, and B. Zhu ${ }^{25}$ \\ ${ }^{1}$ Sino-French Institute for Earth System Science, College of Urban and Environmental Sciences, Peking University, \\ Beijing 100871, China \\ ${ }^{2}$ Institute of Tibetan Plateau Research, Chinese Academy of Sciences, Beijing 100085, China \\ ${ }^{3}$ Center for Global Environmental Research, National Institute for Environmental Studies, Tsukuba, Ibaraki 305-8506, Japan \\ ${ }^{4}$ Institute of Geographic Science and Natural Resources Research, Chinese Academy of Sciences, Beijing 100101, China \\ ${ }^{5}$ Institute of Botany, Chinese Academy of Sciences, Xiangshan, Beijing 100093, China \\ ${ }^{6}$ Laboratoire des Sciences du Climat et de l'Environnement, CEA CNRS UVSQ, 91191 Gif sur Yvette, France \\ ${ }^{7}$ Department of Earth and Ecosystem Sciences, Lund University, Sölvegatan 12, 22362 Lund, Sweden \\ ${ }^{8}$ Environmental Sciences Division, Oak Ridge National Laboratory, Oak Ridge, TN 37831-6290, USA \\ ${ }^{9}$ Institute for Biogeochemistry and Marine Chemistry, Klimacampus, Universität Hamburg, Bundesstrasse 55, \\ 20146 Hamburg, Germany \\ ${ }^{10}$ Centre for Ecology and Hydrology, Benson Lane, Wallingford OX10 8BB, UK \\ ${ }^{11}$ Department of Geosciences, Princeton University, Princeton, NJ, USA \\ ${ }^{12}$ National Center for Atmospheric Research, Boulder, Colorado, USA \\ ${ }^{13}$ Centre for Ecology and Hydrology, Bush Estate, Penicuik, Midlothian EH26 0QB, UK \\ ${ }^{14}$ Chinese Research Academy of Environmental Sciences, Beijing 100012, China \\ ${ }^{15}$ Department of Animal \& Plant Sciences, University of Sheffield, Sheffield S10 2TN, UK \\ ${ }^{16}$ Applied Physics Laboratory, University of Washington, Seattle, WA, USA \\ ${ }^{17}$ Xinjiang institute of ecology and geography, Chinese Academy of Sciences, Urumqi 830011, China \\ ${ }^{18}$ River Basin Research Center, Gifu University, Gifu 501-1193, Japan \\ ${ }^{19}$ Laboratory for Ecological Forecasting and Global Change, College of Forestry, Northwest A \& F University, Yangling, \\ Shaanxi 712100, China \\ ${ }^{20}$ Department of Biology Sciences, Institute of Environment Sciences, University of Quebec, Montreal, Canada \\ ${ }^{21}$ School of Geography, University of Exeter, Exeter EX4 4QF, UK \\ ${ }^{22}$ Ecosystem Dynamics and Global Ecology Laboratory, School of Forestry and Wildlife Sciences, Auburn University, \\ Auburn 36849, USA \\ ${ }^{23}$ Max Planck Institute for Biogeochemistry, P.O. Box 1001 64, 07701 Jena, Germany \\ ${ }^{24}$ Department of Atmospheric and Oceanic Science, University of Maryland, College Park, MD 20740, USA \\ ${ }^{25}$ Department of Horticulture, Cornell University, Ithaca, NY 14853, USA
}

Correspondence to: S. L. Piao (slpiao@pku.edu.cn)

Received: 27 February 2012 - Published in Biogeosciences Discuss.: 29 March 2012 Revised: 6 August 2012 - Accepted: 15 August 2012 - Published: 7 September 2012 
Abstract. This REgional Carbon Cycle Assessment and Processes regional study provides a synthesis of the carbon balance of terrestrial ecosystems in East Asia, a region comprised of China, Japan, North and South Korea, and Mongolia. We estimate the current terrestrial carbon balance of East Asia and its driving mechanisms during 1990-2009 using three different approaches: inventories combined with satellite greenness measurements, terrestrial ecosystem carbon cycle models and atmospheric inversion models. The magnitudes of East Asia's terrestrial carbon sink from these three approaches are comparable: $-0.293 \pm 0.033 \mathrm{PgC} \mathrm{yr}^{-1}$ from inventory-remote sensing model-data fusion approach, $-0.413 \pm 0.141 \mathrm{PgC} \mathrm{yr}^{-1}$ (not considering biofuel emissions) or $-0.224 \pm 0.141 \mathrm{PgC} \mathrm{yr}^{-1}$ (considering biofuel emissions) for carbon cycle models, and $-0.270 \pm 0.507 \mathrm{PgC} \mathrm{yr}^{-1}$ for atmospheric inverse models. Here and in the following, the numbers behind \pm signs are standard deviations. The ensemble of ecosystem modeling based analyses further suggests that at the regional scale, climate change and rising atmospheric $\mathrm{CO}_{2}$ together resulted in a carbon sink of $-0.289 \pm$ $0.135 \mathrm{PgC} \mathrm{yr}^{-1}$, while land-use change and nitrogen deposition had a contribution of $-0.013 \pm 0.029 \mathrm{PgC} \mathrm{yr}^{-1}$ and $-0.107 \pm 0.025 \mathrm{PgC} \mathrm{yr}^{-1}$, respectively. Although the magnitude of climate change effects on the carbon balance varies among different models, all models agree that in response to climate change alone, southern China experienced an increase in carbon storage from 1990 to 2009, while northern East Asia including Mongolia and north China showed a decrease in carbon storage. Overall, our results suggest that about $13-27 \%$ of East Asia's $\mathrm{CO}_{2}$ emissions from fossil fuel burning have been offset by carbon accumulation in its terrestrial territory over the period from 1990 to 2009. The underlying mechanisms of carbon sink over East Asia still remain largely uncertain, given the diversity and intensity of land management processes, and the regional conjunction of many drivers such as nutrient deposition, climate, atmospheric pollution and $\mathrm{CO}_{2}$ changes, which cannot be considered as independent for their effects on carbon storage.

\section{Introduction}

Quantifying the ability of regional terrestrial ecosystems to remove anthropogenic $\mathrm{CO}_{2}$ emissions brings understanding of the global carbon cycle and provides options for policy (Gurney et al., 2009). The East Asia region in RECCAP (Canadell et al., 2011) includes China, Japan, North and South Korea, and Mongolia, located on the East Eurasian continent in the Northern Hemisphere. This region covers a land area of $12 \times 10^{6} \mathrm{~km}^{2}$ and a range of 49 degrees latitude and 72 degrees longitude amounting to $28 \%$ of the Asian continent land area. The population of East Asia has increased by 40.46 million (China, Japan and South Korea contribute $92.8 \%, 2.5 \%$ and $2.7 \%$ of this total increase, re- spectively) since 1980 (UN, 2009). East Asia has also been characterized by rapid economic development and fast GDP increase. According to data from World Bank, China alone accounted for approximately $11 \%$ of the increase in total global GDP from 1980 to 2009, and Japan contributed another $8.6 \%$ (World Bank, 2009). Fossil fuel emissions of $\mathrm{CO}_{2}$ in East Asia are rising significantly with GDP, with moderate gains in the carbon intensity (ratio of emissions-toGDP) (Raupach et al., 2007). Based on the recent IEA statistics of $\mathrm{CO}_{2}$ emissions from fuel combustion (International Energy Agency, 2011), East Asian fossil fuel $\mathrm{CO}_{2}$ emissions observably increased by a factor of two between 1990 and 2009 , becoming an average source of $1.5 \mathrm{Pg} \mathrm{C} \mathrm{yr}^{-1}$ to the atmosphere from 1990 to 2009 (Fig. 1). This regional emission represents a fraction of about $23 \%$ of global fossil fuel $\mathrm{CO}_{2}$ emissions during the same period, and this fraction increased from $18 \%$ in 1990 to $30 \%$ in 2009 (International Energy Agency, 2011). Such a rapid increase in fossil fuel emissions is the first important motivation for studying the carbon balance over East Asia.

The second important motivation for studying the carbon balance over East Asia is the rapid land-use change going on in this region. For example, fast urbanization has occurred in East Asia since the 1990s. The World Urbanization Prospects (2009) shows that the percentage of urban population (the ratio of the urban population to the total population of a given region) in East Asia increased from $32 \%$ in 1990 to $50 \%$ in 2010 (UN, 2009; Sun et al., 2010a), and is still growing. In 2025, Tokyo, Japan, is likely to become the largest city in the world, with its population approaching 37.1 million. Shanghai, China, is projected to be the 9th largest city, with a population of 15 million (UN, 2009). Besides urbanization trends, East Asia also experienced large afforestation over the last three decades. Based on the latest report by FAO (Food and Agriculture Organization of the United Nations) on Global Forest Resources Assessment (FAO, 2010), the annual change in forest area of East Asia increased from $1.76 \times 10^{6}$ ha in $1990-2000$ to $2.78 \times 10^{6}$ ha in $2000-2010$. It is worth noting that East Asia has higher yearly growth in forest area over 2000-2010 (1.2\% per year) than any other country or region (FAO, 2010). Such afforestation mainly occurs in China, whereas Japan and Korea are already highly forested countries $68 \%$ and $65 \%$ forest cover in the early 1990 s, respectively) (FAO, 2010). The Chinese government has developed several large-scale forest plantation programs (e.g. Three-North Protective Forest Program, Taihang Mountains Greening Project, South China Timber Program, the Pearl River Protective Forest Project, and the Yangtze River Protective Forest Project) since the late 1970s (Shen, 1999), leading to an increase of forest area at $1.6 \% \mathrm{yr}^{-1}$ over the last two decades. The annual increasing rate of Chinese forest area increased from $1.99 \times 10^{6}$ ha per year during 1990-2000 to $2.99 \times 10^{6}$ ha per year during 2000-2010 (FAO, 2010). In Japan, forestation programs were developed after World War II for providing timbers construction materials. Because 
of drastic shifts in life style and industrial structure, these young forests are harvested for less than their annual wood increment, resulting in carbon sequestration mainly in woody biomass (Fang et al., 2005).

The third important motivation for studying the carbon balance over East Asia concerns regional climate trends. As a sensitive region of the climate system (Fu et al., 2004; Piao et al., 2010), East Asia experienced significant climate changes in the past decades. According to CRU (Climate Research Unit) climate data (Mitchell and Jones, 2005), mean annual temperature over East Asia has increased by $0.04^{\circ} \mathrm{C} \mathrm{yr}^{-1}$ over the last three decades, a higher rate than the observed global land surface temperature trend $\left(0.03{ }^{\circ} \mathrm{C} \mathrm{yr}^{-1}\right)$ (Fig. 2). Associated with this warming, significant changes in precipitation patterns are observed (Fig. 2). The drier northern China (except the northwest part) has been receiving less precipitation in summer and autumn, whereas the wetter southern China has seen more rainfall during summer and winter (Piao et al., 2010).

The fourth important motivation for studying the carbon balance over East Asia is the rapid change in atmospheric composition caused by industrial and agricultural emissions from this region. The concentration of reactive nitrogen deposition has doubled worldwide and is five times higher than the 1860 level in East Asia as a result of intensive fertilizer use and fossil fuel burning (Galloway et al., 2004; Churkina et al., 2007). For instance, dry deposition of $\mathrm{NO}_{2}$ in China rose by about $8 \%$ from 1990 to 2003 (Lu and Tian, 2007). Apart from nitrogen deposition, tropospheric ozone pollution also characterizes atmospheric composition changes over East Asia. Because East Asia, particularly China, is on the road of rapid economic development, the emissions of ozone precursors that were still at low concentrations in the 1970s dramatically increased in the past decade (Richter et al., 2005) and are larger than North American and European emissions (Akimoto, 2003). Some Chinese regions such as the North China Plain, the Yangtze River Delta and the Pearl River Delta are significantly affected by ozone pollution (Dufour et al., 2010). At the end of the last century, tropospheric ozone concentrations in these areas had reached a high level, higher than any other areas of the northern mid-latitudes (Oltmans et al., 1998; Lee et al., 1998), and are projected to further increase in the future (Akimoto, 2003).

There is no doubt that the changes in regional economic and climatic drivers of ecosystem $\mathrm{CO}_{2}$ fluxes mentioned above affect the carbon balance of East Asia. In comparison to other regions such as Europe (Janssens et al., 2003; Ciais et al., 2010) and North America (Pacala et al., 2001; Crevoisier et al., 2010), our knowledge on the carbon budget of terrestrial territory in East Asia remains rather limited because most studies focused mainly on national $\mathrm{C}$ budget estimates (Piao et al., 2010; Ichii et al., 2010; Tian et al., 2011). Recently, Piao et al. (2011a) used three different terrestrial carbon cycle models to estimate changes in the carbon balance of East Asian ecosystems over the last century, but that

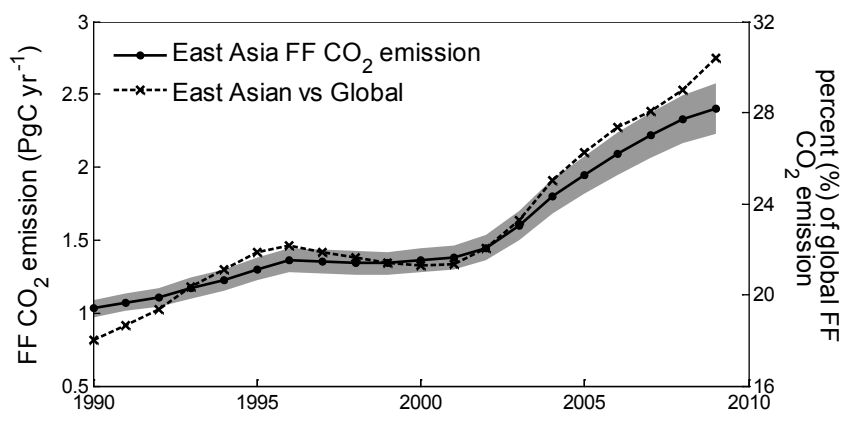

Fig. 1. Change in fossil fuel $\mathrm{CO}_{2}$ emissions ( $\mathrm{FF} \mathrm{CO} 2$ emission) over East Asia and its relative contribution to global fossil fuel $\mathrm{CO}_{2}$ emissions, from 1990 to 2007. Data acquired from IEA statistics. Grey area shows 1-sigma standard error of the fossil fuel $\mathrm{CO}_{2}$ emission estimates.

study only considered climate and rising atmospheric $\mathrm{CO}_{2}$ forcing. The primary objective of this paper is to quantify the $\mathrm{C}$ balance of East Asia's terrestrial ecosystems over the last two decades as well as its drivers and uncertainties. To do so, we use three different approaches: a bottom-up approach derived from biomass and soil carbon inventory data and combined with satellite observations of vegetation greenness (NDVI: Normalized Difference Vegetation Index), terrestrial ecosystem carbon cycle models, and a top-down approach based on atmospheric $\mathrm{CO}_{2}$ observation data and inversion of atmospheric transport.

\section{Methods}

\subsection{Inventory- and satellite-based estimation}

East Asia contains almost all major forest types of the Northern Hemisphere including tropical rain forest, subtropical evergreen broadleaf forest, deciduous broadleaf forest, broadleaf and needleleaf mixed forest and deciduous needleleaf forest from south to north. According to the latest report by FAO on Global Forest Resources Assessment (FAO, 2010), the total forest area of East Asia is about $2.54 \times 10^{8}$ ha in 2010 , accounting for about $6 \%$ of global total forest area. In this study, forest biomass carbon sink is assessed based on FAO reports (FAO, 2010) and previous published estimates. We only selected literature data that used national forest inventories to calculate forest biomass change. The relatively systematic and spatially extensive forest inventory data provide one of the key sources for estimating the basic elements of forest $\mathrm{C}$ stock and stock change at the country scale, although there are large uncertainties associated with allometry, non-measured soil $\mathrm{C}$ pools, and sampling of disturbed forests (Phillips et al., 2000; Pan et al., 2004, 2011).

Grassland is a widespread vegetation type in East Asia. Temperate grasslands are distributed in arid and semi-arid 

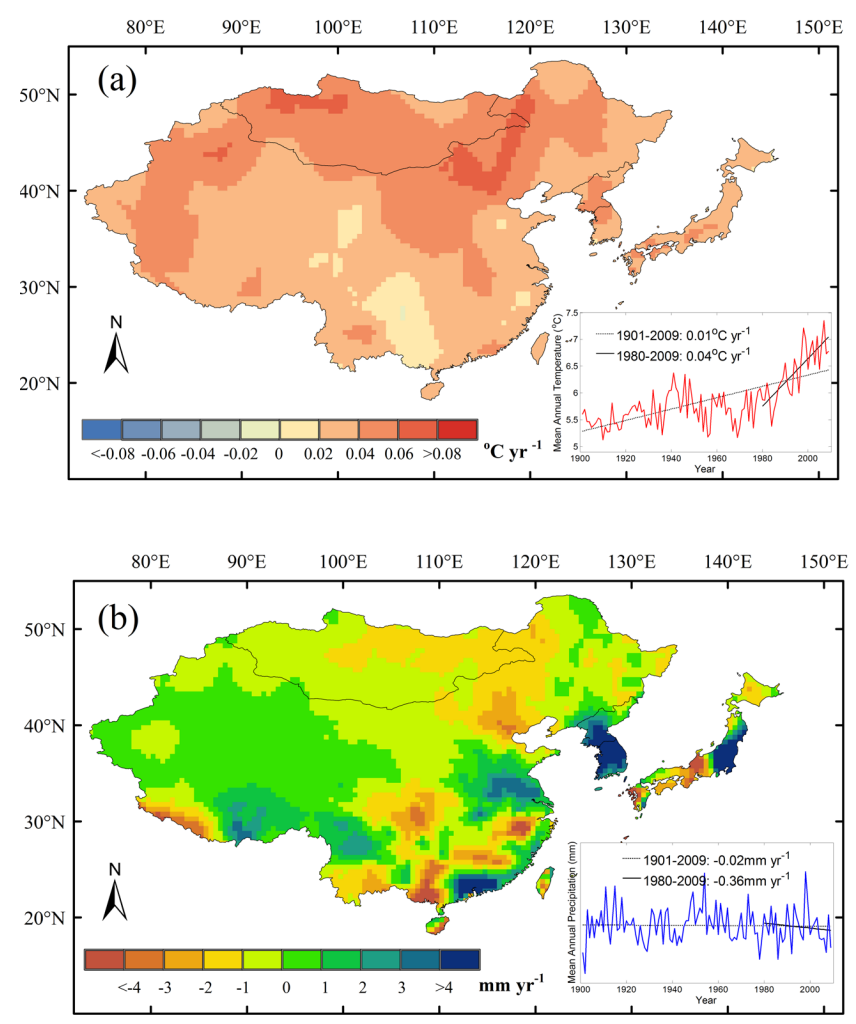

Fig. 2. Climate change in East Asia. (a) Spatial pattern of trend in mean annual temperature (MAT) from 1970 to 2009. (b) Spatial pattern of trend in mean annual precipitation (MAP) from 1970 to 2009. Inset figures show interannual variability of MAT and MAP averaged over the whole region.

regions, while cold alpine grasslands are spread mainly over the Tibetan Plateau and some high elevation mountainous area. Here, we estimate grassland biomass change using satellite NDVI observations and the empirical approach developed by Piao et al. (2007) (see Supplement Text S1). The NDVI data used are from the Global Inventory Monitoring and Modeling Studies (GIMMS) group derived from the National Oceanic and Atmospheric Administration's Advanced Very High Resolution Radiometer (NOAA/AVHRR) land dataset at a spatial resolution of $8 \times 8 \mathrm{~km}$ and a 15-day interval for the period January 1982 to December 2009 (Tucker et al., 2005; Wang et al., 2011). Information on the fractional coverage of grassland in China was derived from the Map of Grassland Resources in China at 1:4000 000 scale (Commission for Integrated Survey of Natural Resources, 1996), and information in other regions is from the UMD Global Land Cover Classification at $8 \times 8 \mathrm{~km}$ resolution (DeFries et al., 1998).

Shrublands in East Asia are mainly distributed in China (DeFries et al., 1998), with an area approximating $2.1 \times$ $10^{7}$ ha (Commission for Integrated Survey of Natural Resources, 1996) mainly dispersed over mountainous areas, in particular in southwestern, southern and northeastern China.
Similar to the estimation of grassland biomass change, a satellite-based empirical approach (Piao et al., 2009a) was applied to estimate biomass change for shrubland in East Asia (Supplement Text S1).

Carbon accumulated in wood products must be considered in the estimation of the regional carbon balance (Ciais et al., 2008). In Europe, wood products represent a $\mathrm{C}$ sink of $-0.024 \mathrm{PgC} \mathrm{yr}^{-1}$ (Ciais et al., 2008). Based on FAO data (http://www.fao.org/waicent/portal/statistics en.asp), the wood products in East Asia are about $43 \%$ than those in Europe. As distinguishing long-lived and short-lived wood products requires detailed wood product statistics in categories which are not accessible for all East Asian countries, we apply the ratio of wood production to carbon storage change in wood products estimated in Europe (Kohlmaier et al., 2007; Ciais et al., 2008) to estimate the C sink of wood products in East Asia.

Soils are the largest source of uncertainty in the terrestrial ecosystem carbon balance at regional and country scales, as data are lacking from repeated inventories (Huang et al., 2010). Here, change in soil carbon storage of natural ecosystems (forest, shrubland, and grassland) in East Asia is estimated using biomass change estimated for each biome as specified above, and the ratio of soil-to-biomass carbon storage change in China reported in previous studies (Piao et al., 2009a; Tian et al., 2011). For cropland, soil organic carbon (SOC) changes and uncertainties are provided through a synthesis of literature data (Huang et al., 2010).

It has been suggested that riverine export of dissolved inorganic and organic carbon (DIC and DOC) and particulate organic carbon (POC) makes a considerable contribution to the budget of carbon stock (Ciais et al., 2008; Cai et al., 2008). The lateral transport of carbon to the coast was estimated at the river basin scale using the Global $\mathrm{Nu}-$ trient Export from WaterSheds (NEWS) model framework (Mayorga et al., 2010), including NEWS basin areas. The carbon species models are hybrid empirically and conceptually based models that include single and multiple linear regressions developed by the NEWS effort and Hartmann et al. (2009), and single regression relationships assembled from the literature. Modeled dissolved and particulate organic carbon (DOC and POC) loads used here (from Mayorga et al., 2010) were generated largely using drivers corresponding to the year 2000, including observed hydroclimatological forcings, though some parameters and the observed loads are based on data spanning the previous two decades. The amounts of riverine DIC export are provided by Hartmann et al. (2009). Carbon, sediment and water exports were aggregated from the river basin scale to coastal segmentation regions (COSCAT, Meybeck et al., 2006).

\subsection{Ecosystem models}

Process-based terrestrial ecosystem models have been applied to assess the dynamics of the terrestrial carbon cycle 
(Morales et al., 2005). Ecosystem model results, however, generally depend to an unknown extent on model parameter values (Mitchell et al., 2009), climate and soil forcing data (Zhao et al., 2012), initial conditions (Carvalhais et al., 2008), and on model structure (Lin et al., 2011), although data assimilation techniques are developing and may enable us to determine optimal parameter values in an objective manner (Santaren et al., 2007). Accordingly, analyses with an ensemble of independent models are preferable to assess the uncertainties due to model structure and parameter choices (Friedlingstein et al., 2006; Sitch et al., 2008). In this study, we estimated the carbon balance of terrestrial ecosystems in East Asia using 10 ecosystem models: HyLand (Levy et al., 2004), Lund-Potsdam-Jena DGVM (Sitch et al., 2003), ORCHIDEE (Krinner et al., 2005), Sheffield-DGVM (Woodward et al., 1995; Woodward and Lomas, 2004), TRIFFID (Cox, 2001), LPJ-GUESS (Smith et al., 2001), NCAR-CLM4CN (Oleson et al., 2010; Lawrence et al., 2011), OCN (Zaehle and Friend, 2010), VEGAS (Zeng, 2003; Zeng et al., 2005), and VISIT (Ito, 2008). Detailed descriptions of the surface fluxes of $\mathrm{CO}_{2}$, water and the dynamics of water and carbon pools in response to environmental change in each model can be found in the corresponding literature. Previous studies (e.g. Tao and Zhang, 2010; Tan et al., 2010) have applied some of these models in estimating vegetation and carbon dynamics over different parts of East Asia.

Following the historical climate-carbon cycle model intercomparison project (Trendy) protocol (http://dgvm.ceh.ac. uk/system/files/Trendy_protocol\%20_Nov2011_0.pdf), each model was run from its equilibrium (assumed at the beginning of the 1900s) to 2009. All the models consider change in climate and rising atmospheric $\mathrm{CO}_{2}$ concentration (simulation S2), while 9 of 10 models run a factorial simulation considering only rising atmospheric $\mathrm{CO}_{2}$ (simulation $\mathrm{S} 1$ ). Only three models account for $\mathrm{N}$ limitation on vegetation productivity (Sheffield-DGVM, NCAR-CLM4CN and OCN). The spatial resolution of each simulation differs among models (Table 1).

The historical changes in atmospheric $\mathrm{CO}_{2}$ for the period 1901-2009 are derived from ice core records and atmospheric observations (Keeling and Whorf, 2005). For the climate forcing datasets, monthly climate data for the period 1901-2009 from CRU-NCEP datasets with a spatial resolution $0.5^{\circ} \times 0.5^{\circ}$ (http://dods.extra.cea.fr/data/p529viov/ cruncep/) were used in all models. Information on atmospheric nitrogen deposition for NCAR-CLM4CN and OCN was taken from Jean-François Lamarque (personal communication) and Dentener et al. (2006), respectively.

\subsection{Atmospheric inversion models}

The spatio-temporal characterization of atmospheric $\mathrm{CO}_{2}$ concentration between different stations provides integrated constraints to the net land-atmosphere $\mathrm{CO}_{2}$ exchange. In- verse models, referred to as the "top-down" approach, infer spatial patterns of land-atmosphere $\mathrm{CO}_{2}$ fluxes and their variability using atmospheric $\mathrm{CO}_{2}$ concentration measurements made at a surface network of about 100 stations, atmospheric transport modeling, and prior information on land and ocean fluxes as well as on fossil fuel $\mathrm{CO}_{2}$ emissions in the case of Bayesian synthesis inversions (Enting et al., 1995; Gurney et al., 2002; Peylin et al., 2005). There are large uncertainties in inversion estimates of regional $\mathrm{CO}_{2}$ fluxes, particularly for a region like East Asia where the surface network is sparse ( 9 stations over North Asia). Inversion results are also sensitive to biases in transport models and to biases in the assumed magnitude and distribution of fossil fuel emissions (Peylin et al., 2005; Gurney et al., 2005). One advantage, however, of inversions is that they provide an estimation encompassing all surface sources and sinks of $\mathrm{CO}_{2}$, in principle with an uncertainty which propagates random error on prior fluxes and on atmospheric measurements and models (Enting et al., 1995). By contrast with the top-down approach of inversions, there is a risk of bias in omitting important processes or ecosystems (e.g. wetlands and urban ecosystems) in inventories and ecosystem carbon cycle modeling (bottom-up approaches), described above. Here, we provide carbon balance estimates from seven inversions, carried out by the TRANSCOM (Baker et al., 2006) modelers and made available for the REC$\mathrm{CAP}$ project. The inversions giving $\mathrm{CO}_{2}$ flux estimates for at least 10 years during 1990-2009 are adopted in our study (Peylin et al., 2011). They are C13_CCAM, C13_MATCH, JENA_S96, JMA_2010, NICAM, NIES, and PYVAR. In addition, the net $\mathrm{CO}_{2}$ land-atmosphere fluxes estimated by the CarbonTracker (CTRACKER_US, Peters et al., 2007) in 2000-2009 are also considered. The study period of each inverse model simulation is provided in Table 2.

In atmospheric inversions, uncertainties treated as Gaussian purely random errors formally account for uncertain prior fluxes, uncertain atmospheric measurements and uncertain capabilities of transport models to represent these measurements (see Ciais et al., 2010, for instance, for an overview). In the RECCAP inversions used in this study over East Asia, however, the optimized flux does not account for prior flux uncertainties in fossil fuel combustion $\mathrm{CO}_{2}$ emissions. In other words, each inversion prescribes to the atmospheric transport model fossil fuel emissions assumed of perfectly known global magnitude and spatio-temporal distribution. To minimize the influence of inter-model differences in assumed fossil fuel emissions in estimating landatmospheric $\mathrm{CO}_{2}$ fluxes, adjustments were made by adding posterior land-atmospheric fluxes of each model with the difference between assumed fossil fuel emissions by the model and the common fossil fuel emissions (EDGAR3.2 Fast Track 2000 emission database, Olivier et al., 2001). In order to account for regional fossil fuel $\mathrm{CO}_{2}$ emissions uncertainty, which is particularly large when a fast developing economy such as China is included in a region (Gregg et 
Table 1. Carbon balance derived by different carbon cycle models.

\begin{tabular}{|c|c|c|c|c|}
\hline Model name (abbreviation) & Spatial resolution & $\begin{array}{l}\text { Net ecos } \\
\mathrm{S} 1^{1}\end{array}$ & $\begin{array}{l}\text { stem carbon balance }\left(\mathrm{Pg} \mathrm{C} \mathrm{yr}^{-1}\right) \\
\mathrm{S} 2^{1}\end{array}$ & References \\
\hline Community Land Model 4CN (CLM4CN) & $0.5^{\circ} \times 0.5^{\circ}$ & -0.284 & -0.300 & Oleson et al. (2010); Lawrence et al. (2011) \\
\hline Hyland (HYL) & $3.75^{\circ} \times 2.5^{\circ}$ & -0.317 & -0.344 & Friend et al. (1997); Levy et al. (2004) \\
\hline Lund-Postdam-Jena (LPJ) & $3.75^{\circ} \times 2.5^{\circ}$ & -0.296 & -0.216 & Stich et al. (2003) \\
\hline LPJ-GUESS & $0.5^{\circ} \times 0.5^{\circ}$ & -0.648 & -0.474 & Smith et al. (2001) \\
\hline ORCHIDEE-CN (OCN) & $3.75^{\circ} \times 2.5^{\circ}$ & -0.303 & -0.274 & Zaehle and Friend (2010); Zaehle et al. (2010) \\
\hline ORCHIDEE (ORC) & $0.5^{\circ} \times 0.5^{\circ}$ & -0.240 & -0.203 & Krinner et al. (2005) \\
\hline Sheffield-DGVM (SDGVM) & $3.75^{\circ} \times 2.5^{\circ}$ & -0.338 & -0.344 & Woodward et al. (1995) \\
\hline TRIFFID (TRI) & $3.75^{\circ} \times 2.5^{\circ}$ & -0.206 & -0.183 & $\operatorname{Cox}(2001)$ \\
\hline VEGAS & $2.5^{\circ} \times 2.5^{\circ}$ & -0.051 & -0.051 & Zeng et al. (2005) \\
\hline VISIT & $0.5^{\circ} \times 0.5^{\circ}$ & N.A. ${ }^{2}$ & -0.497 & Ito (2008) \\
\hline
\end{tabular}

${ }^{1}$ Two model simulation experiments, noted by S1 and S2, are set in Trendy protocol. In the S1 experiment, models were forced with rising atmospheric CO ${ }_{2}$, recycled climate of the early 20 th century, and constant land use; in the $\mathrm{S} 2$ experiment, models were forced with rising atmospheric $\mathrm{CO}_{2}$, observed climate, and constant land use. Negative values indicate carbon sink.

${ }^{2} \mathrm{~S} 1$ simulation by VISIT model is not available.

Table 2. Carbon balance derived by different atmospheric inverse models. Negative values indicate carbon sink.

\begin{tabular}{llrl}
\hline Name & Study Period & $\begin{array}{r}\text { Carbon balance } \\
\left(\mathrm{Pg} \mathrm{C} \mathrm{yr}^{-1}\right)\end{array}$ & Reference \\
\hline C13_CCAM & $1992-2008$ & -0.997 & Law et al. (2006) \\
C13_MATCH & $1992-2008$ & 0.416 & Rasch et al. (1997) \\
JENA_S96 & $1996-2009$ & -0.930 & Rödenbeck et al. (2003) \\
JMA_2010 & $1985-2008$ & 0.201 & Taguchi (1996) \\
NICAM & $1988-2007$ & -0.404 & Satoh et al. (2008) \\
NIES & $1993-2007$ & -0.641 & Maksyutov et al. (2008) \\
PYVAR & $1988-2008$ & -0.376 & Chevallier et al. (2005) \\
CTRACKER_US & $2000-2009$ & -0.312 & Peters et al. (2007) \\
\hline
\end{tabular}

al., 2008), we added to the inversion uncertainties from the RECCAP-East Asia study the estimated standard error (one $\sigma$ ) of fossil fuel emissions of each East Asian country $(8.9 \%$ for China and North Korea, 2.0\% for Japan, 7.6\% for Mongolia and $6.2 \%$ for South Korea, Andres et al., personal communication). The inter-model errors and fossil fuel emissions errors are propagated assuming that they are independent.

\subsection{Uncertainty estimates}

The uncertainties of the carbon flux components were estimated using two methods. First, when the data product includes a formal uncertainty analysis, the provided uncertainty estimates are used in our reports. Second, when there are several independent estimates of the same flux component with the same method (e.g. the net land-atmospheric $\mathrm{CO}_{2}$ exchange estimated by inverse models), the standard deviation of the independent estimates is reported as their uncertainty. The standard deviation usually underestimates the uncertainty when there are only a few samples; in this case, we also give the range of the independent estimates. When only one sample is available for some flux component within one method and when this sample does not have a documented uncertainty, we do not estimate its uncertainty.

When summing several flux contributions that are estimated independently, we quadratically sum the correspond- ing uncertainty standard deviations to document the resulting uncertainty.

\section{Results and discussion}

\subsection{Inventory- and satellite-based estimation}

\subsubsection{Forest biomass accumulation}

In East Asia, forest area is significantly increased from $2.09 \times 10^{6} \mathrm{~km}^{2}$ in 1990 to $2.55 \times 10^{6} \mathrm{~km}^{2}$ in 2010 , most of this increase being in China. According to the latest report of FAO on Global Forest Resources Assessment (FAO, 2010), Chinese forest increased by $2.49 \times 10^{4} \mathrm{~km}^{2}$ per year during the period of 1990-2010. Partly in response to expanding forest area, forest biomass in China is estimated to have increased from 4.4 Pg C in 1990 to $6.2 \mathrm{Pg} \mathrm{C}$ in 2010, resulting in a net sink of $-0.09 \mathrm{Pg} \mathrm{Cyr}^{-1}$ over the last two decades (Supplement Table S1). This estimation based on FAO data is very close to the recent synthesis of Pan et al. (2011), who inferred a biomass carbon sink of $-0.06 \mathrm{Pg} \mathrm{C} \mathrm{yr}^{-1}$ during the $1990 \mathrm{~s}$, and that of $-0.115 \mathrm{Pg} \mathrm{C} \mathrm{yr}^{-1}$ during the period of 2000-2007 (average of $-0.084 \mathrm{Pg} \mathrm{C} \mathrm{yr}^{-1}$ over the past two decades). Owing primarily to the growth of relatively young stands (age of 40-60 yr) Japanese forests are estimated to be a net $\mathrm{C}$ sink in the range $-0.024--0.019 \mathrm{Pg} \mathrm{C} \mathrm{yr}^{-1}$ over the last two decades (FAO, 2010; Pan et al., 2011). In contrast, due to the decrease in forest area in Mongolia (loss of $8.19 \times$ $10^{2} \mathrm{~km}^{2}$ per year) and North Korea (loss of $1.27 \times 10^{3} \mathrm{~km}^{2}$ per year) during $1990 \mathrm{~s}$ and $2000 \mathrm{~s}$, forest biomass in these two countries has decreased (most likely transformed as $\mathrm{CO}_{2}$ emitted to the atmosphere) at a rate of $0.004 \mathrm{Pg} \mathrm{C} \mathrm{yr}^{-1}$ and $0.003 \mathrm{Pg} \mathrm{C} \mathrm{yr}^{-1}$, respectively. In South Korea, despite the fact that the area of forest shrunk from $6.37 \times 10^{4} \mathrm{~km}^{2}$ in 1990 to $6.22 \times 10^{4} \mathrm{~km}^{2}$ to 2010 , biomass increased by 0.008 $0.009 \mathrm{Pg} \mathrm{Cyr}^{-1}$ (FAO, 2010; Pan et al., 2011), which is related to re-growth of young forests established in the early 1970s (Choi et al., 2004). Overall, based on national forest inventory data compiled by FAO, we obtain an average 


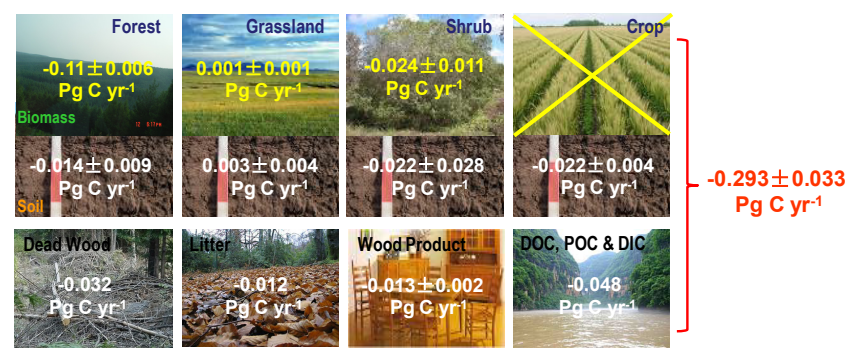

Fig. 3. The inventory- and satellite-based approach estimated a carbon sink in terrestrial ecosystems in East Asia and its components over the last two decades. A negative value indicates net carbon sink.

net forest biomass $\mathrm{C}$ sink of $-0.11 \pm 0.006 \mathrm{Pg} \mathrm{C} \mathrm{yr}^{-1}$ over East Asia during the period 1990-2009 (Fig. 3, Supplement Table S1). This represents about $9 \%$ of the total northern forest C sink (Pan et al., 2011). Comparatively, East Asia's forest biomass $\mathrm{C}$ sink was close to those of Europe $\left(-0.14--0.08 \mathrm{PgC}^{-1}\right)$ and the United States $(-0.13-$ $-0.12 \mathrm{Pg} \mathrm{C} \mathrm{yr}^{-1}$ ) (FAO, 2010; Pan et al., 2011; Luyssaert et al., 2010).

\subsubsection{Shrublands biomass change}

Although shrubland ecosystems are widespread in China (Wu, 1980; IGCAS, 1996), there is very limited data available to ascertain $\mathrm{C}$ stock changes. In North America, the expansion of shrubland ecosystems in arid regions, called "woody encroachment", was estimated to be a sink of $-0.12 \mathrm{Pg} \mathrm{C} \mathrm{yr}^{-1}$, accounting for $18-34 \%$ of the total coterminous US carbon sink (Pacala et al., 2001). In China, changes in energy production systems in rural areas and movement of rural populations to cities have likely diminished the collection of fuel wood, and thus accelerated the recovery of shrubland and woodland vegetation. Shrublands were estimated to increase their biomass by $0.022 \pm 0.01 \mathrm{Pg} \mathrm{C} \mathrm{yr}^{-1}$ over the last two decades of the 20th century (Piao et al., 2009a), determined using an indirect estimation approach based upon site-level data and NDVI trends. Extending the approach of Piao et al. (2009a) based on NDVI-biomass regressions between sites extrapolated in time to shrublands over the entire East Asia region, we estimate that shrubland biomass $\mathrm{C}$ stocks over East Asia have increased by an average sink of $-0.024 \pm 0.011 \mathrm{Pg} \mathrm{C} \mathrm{yr}^{-1}$ and have an uncertainty of about $50 \%$ (estimated from the scatter around the linear regression line between NDVI and shrubland biomass at 34 available sites) (Fig. 3).

\subsubsection{Grasslands biomass change}

Grassland ecosystems in the world may contribute as much as $20 \%$ of total terrestrial production and could be potential C sinks (Scurlock and Hall, 1998), but the direct evidence is very limited. In China, several studies have suggested that grassland biomass significantly increased from early 1980s to late 1990s (Piao et al., 2007), followed by a decreasing trend over the last decade due to an increase in drought driven by reduced summer precipitation and rising temperature, and due to overgrazing by livestock (Jeong et al., 2011; Piao et al., 2011b; Peng et al., 2011). Consequently, our NDVIbiomass regression approach (see Methods section) in this study indicates that grassland biomass in East Asia is relatively stable with a slight decline $0.001 \pm 0.001 \mathrm{Pg} \mathrm{C} \mathrm{yr}^{-1}$ (Fig. 3). It should be noted that the uncertainties of this estimation may be underestimated, since we did not consider the uncertainties of grassland inventory data, satellite time series datasets, and a belowground carbon stocks estimation approach (Fan et al., 2008).

\subsubsection{Soil carbon changes}

Soils in East Asia contain large carbon stocks, and may play an important role in the regional carbon balance. The increased biomass in forest and shrubland over the last two decades implies that soils may accumulate carbon through increased litterfall during the same period, but there are no observational data from repeated inventories to support this speculation at the regional and country scales. Using the ratios of soil-to-biomass carbon sink calculated for forest $(0.05-0.2)$, shrubland $(0.35-1.8)$, and grassland (0.85-4.4) in China by Piao et al. (2009a) and Tian et al. (2011) in combination with biomass stock changes derived in this study, we estimated soil carbon storage change over East Asia of $0.014 \pm 0.009 \mathrm{Pg} \mathrm{C} \mathrm{yr}^{-1}$ for forests (range from 0.005 to $\left.0.022 \mathrm{PgC} \mathrm{yr}^{-1}\right), 0.022 \pm 0.028 \mathrm{PgC} \mathrm{yr}^{-1}$ for shrublands (range from 0.005 to $0.063 \mathrm{PgC} \mathrm{yr}^{-1}$ ), and $-0.003 \pm 0.004 \mathrm{PgC} \mathrm{yr}^{-1}$ for grasslands (range from -0.009 to $-0.002 \mathrm{Pg} \mathrm{C} \mathrm{yr}^{-1}$ ) (Fig. 3). Compared with natural ecosystems, changes in agricultural practices play a dominant role in controlling cropland soil carbon storage. Several meta-analyses of cropland soil carbon inventory data suggest that the average rate of SOC sequestration in Chinese cropland (area of $130 \mathrm{M}$ ha) was $21.7 \pm 4.3 \mathrm{Tg} \mathrm{C} \mathrm{yr}^{-1}$ between 1980 and 2000 (Huang et al., 2006; Lu et al., 2009; Yu et al., 2009; Pan et al., 2010; Huang et al., 2010; Sun et al., 2010b). Due to lack of information on change in cropland SOC in China after 2000, we used this value to extrapolate the soil carbon increase for the period of 1990-2010 (Fig. 3). Change in cropland soil carbon storage for the other four countries is not taken into account in this study because of lack of available information, but this may not significantly influence our final results on the magnitude of the carbon budget in East Asia due to the relatively small cropland area in these four countries $\left(9.69 \times 10^{4} \mathrm{~km}^{2}\right.$ compared to $1.43 \times 10^{6} \mathrm{~km}^{2}$ in China) (Ramankutty et al., 2008). 


\subsubsection{Wood products change}

In addition to change in biomass and soil carbon storage, one must account for the carbon accumulated in wood products, a component not included in forest inventories but that should be considered in regional estimates of C storage (Pacala et al., 2001). Based on FAO data, we estimated that wood products in China are a sink of $-0.010 \mathrm{PgC}^{-1}$, which is comparable with other current estimates of $-0.008 \mathrm{Pg} \mathrm{Cyr}^{-1}$ (Kohlmaier et al., 2007) and $-0.007 \mathrm{Pg} \mathrm{C} \mathrm{yr}^{-1}$ (Pan et al., 2011). The sum of the carbon sink of wood products for the other four countries in East Asia is about $-0.005 \mathrm{PgC} \mathrm{yr}^{-1}$, suggesting that the carbon accumulated into wood products over East Asia is $-0.013 \pm 0.002 \mathrm{Pg} \mathrm{C} \mathrm{yr}^{-1}$.

\subsubsection{Carbon exported from the land to the ocean}

As a result of "leaching" and physical erosion, a substantial amount of soil organic and plant litter carbon is exported as DOC and POC from the land to the ocean (Ludwig et al., 1996). We estimated riverine export of $9.8 \mathrm{Tg} \mathrm{C} \mathrm{yr}^{-1}$ by DOC and $9.4 \mathrm{Tg} \mathrm{C} \mathrm{yr}^{-1}$ by POC over East Asia from a global synthesis calculated by Emilio Mayorga based on the NEWS approach. The estimates considered here represent net landocean DOC and POC fluxes and do not take into account OC being sedimented within the river system, e.g. in dams, lakes or flood plains, or OC being decomposed during transport. These OC burials in river systems can be substantial and would represent a net loss from the here considered landsurface system (e.g. Tranvik et al., 2009). However, due to lack of quantitative data these fluxes are not included in our study.

The land-river DIC flux sources are partly atmospheric $\mathrm{CO}_{2}$ derived via root respiration and decomposition of DOC and POC in the soil-rock system or are of lithogenic origin (carbonate dissolution). This river DIC is predominantly transported as weathering-derived bicarbonate and carbonate ions to the ocean, while excess $\mathrm{CO}_{2}\left(\mathrm{CO}_{2}\right.$ above the equilibrium level corresponding to the atmospheric $\mathrm{CO}_{2}$ partial pressure) escapes back to the atmosphere. Over East Asia, the net DIC flux from the land to the ocean was estimated to be $0.029 \mathrm{Pg} \mathrm{Cyr}^{-1}$ (cf. Hartmann et al., 2009). It should be noted that lithogenic DIC should be subtracted from the total DIC transported to the oceans, since it is derived from geological carbon stock rather than from the atmosphere. The proportion of lithogenic DIC in the total DIC is probably larger than $33 \%$. We did not consider lithogenic DIC in this study.

Since 1990, carbon accumulated in dead wood over China, Japan and South Korea has increased by about $0.023,0.007$, and $0.002 \mathrm{PgC} \mathrm{yr}^{-1}$, respectively (Pan et al., 2011). In addition, $\mathrm{C}$ storage in China's forest litter has increased by the magnitude of $0.012 \mathrm{Pg} \mathrm{C} \mathrm{yr}^{-1}$. Overall, our inventory- and satellite-based estimation suggests that the East Asian ter- ritory annually has accumulated net $0.293 \pm 0.033 \mathrm{Pg}$ of carbon (range from $\mathrm{C}$ sink of -0.237 to $-0.367 \mathrm{Pg} \mathrm{C} \mathrm{yr}^{-1}$ ) from the atmosphere over the last two decades (Fig. 3, Supplement Table S2).

\subsection{Model attribution of net carbon balance over East Asia}

\subsubsection{Climate change and rising atmospheric $\mathrm{CO}_{2}$ concentration}

To evaluate the effects of climate change on $\mathrm{C}$ balance, we use the difference between net ecosystem carbon balance between terrestrial ecosystems and atmosphere in $\mathrm{S} 1$ and net ecosystem carbon balance in $\mathrm{S} 2$ as the contribution of climate change alone to $\mathrm{C}$ balance over East Asia. Among the nine models (CLM4CN, HYL, LPJ, LPJ-GUESS, OCN, ORCHIDEE, SDGVM, TRI, VEGAS) providing both S1 and S2 simulations, four models (CLM4CN, HYL, SDGVM and HYL) suggest that climate change alone causes a carbon sink in terrestrial ecosystems over East Asia. The average of the nine models for the fraction of net ecosystem carbon balance driven by climate change is $0.033 \pm 0.062 \mathrm{PgC} \mathrm{yr}^{-1}$ (positive values indicate net carbon sources), with a range going from a net carbon source of $0.174 \mathrm{Pg} \mathrm{C} \mathrm{yr}^{-1}$ (LPJ-GUESS) to a net sink of $-0.027 \mathrm{PgC}^{-1}$ (HYL). This relatively small magnitude of net ecosystem carbon balance attributed to climate change results from opposite changes in carbon storage in the southern and northern regions of East Asia (Fig. 4), according to the models. Although the magnitude of the climate change-attributed carbon budget varies among different models, all models agree that in response to climate change alone, southern China experienced an increase in carbon storage from 1990 to 2009, while northern East Asia, including Mongolia and north China, showed a decrease in carbon storage (Fig. 4), likely due to drought. In particular since the late 1990s, northern East Asia, except northwest China, suffered from drought driven by both decreasing precipitation and rising temperature (Park et al., 2010; Piao et al., 2010). Such an increase in drought further caused a decrease in satelliteobserved vegetation growth in northern East Asia (Jeong et al., 2011; Piao et al., 2011b). In southern East Asia where precipitation is abundant, enhanced vegetation productivity driven by current global warming may partly explain climate change-induced net carbon accumulation (Piao et al., 2004).

Since plant photosynthesis is not saturated at the current atmospheric $\mathrm{CO}_{2}$ concentration, previous modeling studies suggested that global vegetation productivity increased significantly in response to rising atmospheric $\mathrm{CO}_{2}$ concentration, which further caused an increase in net carbon uptake of terrestrial ecosystems (Sitch et al., 2007). By considering this $\mathrm{CO}_{2}$ fertilization effect in addition to climate change (simulation S2), all ecosystem carbon cycle models suggest that at the regional scale, terrestrial ecosystems in East Asia act as a carbon sink by an average of 


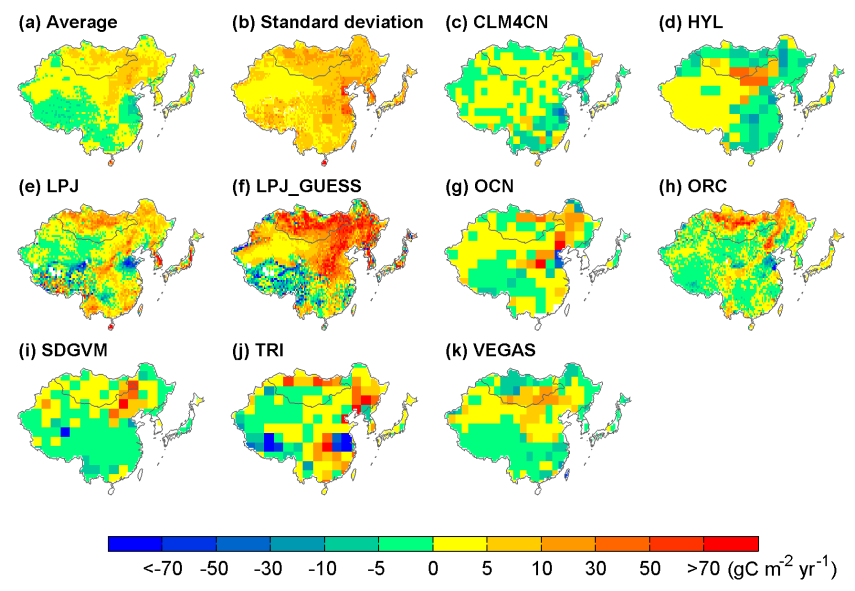

Fig. 4. Nine ecosystem models simulated spatial patterns of net ecosystem carbon balance attributed to climate change (obtained from the difference between simulation S2 and S1) during the period 1990-2009. (a) Average net ecosystem carbon balance from the nine models, (b) standard deviation of the nine model-derived net ecosystem carbon balance, and (c-h) net ecosystem carbon balance estimated by each model. Negative value indicates net carbon sink.

$-0.289 \pm 0.135 \mathrm{Pg} \mathrm{Cyr}^{-1}$ (ranging from $-0.051{\mathrm{PgC} \mathrm{yr}^{-1}}^{-1}$

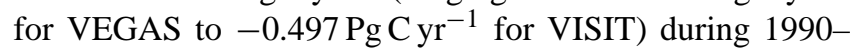
2009. As shown in Fig. 5, it is very likely that most of this carbon sink attributed to climate change and rising $\mathrm{CO}_{2}$ is mainly distributed in southern and eastern China (except LPJ-GUESS).

\subsubsection{Nitrogen deposition}

It is generally accepted that nitrogen deposition enhances carbon sink strength through two mechanisms: (1) stimulated vegetation productivity resulting in increased vegetation biomass (Churkina et al., 2007), and (2) reduced soil organic matter decomposition rates leading to increased soil organic C storage (Pregitzer et al., 2008; Janssens et al., 2010). However, there is an intense debate about the magnitude and possible saturation of the nitrogen-induced carbon sink (Janssens et al., 2010). In Europe, Churkina et al. (2010) estimated that the nitrogen deposition-induced carbon sink is $-0.037--0.030 \mathrm{Pg} \mathrm{C} \mathrm{yr}^{-1}$, while in China, Tian et al. (2011) showed that net carbon accumulation due to nitrogen deposition is larger than that caused by elevated atmospheric $\mathrm{CO}_{2}$. This is inconsistent with the result of the OCN model (Zaehle et al., 2010). Based on the simulation by Tian et al. (2011) using DLEM and TEM models, we estimate annually a sink of about $-0.125 \mathrm{Pg}$ of carbon realized in China's terrestrial ecosystems in response to nitrogen deposition during the period of 1990-2005. This $\mathrm{N}$ depositioninduced carbon sink is larger than estimated by the CLM4CN model, which predicts that the nitrogen deposition-enhanced carbon sink over East Asia is about $-0.089 \mathrm{Pg} \mathrm{C} \mathrm{yr}^{-1}$ from

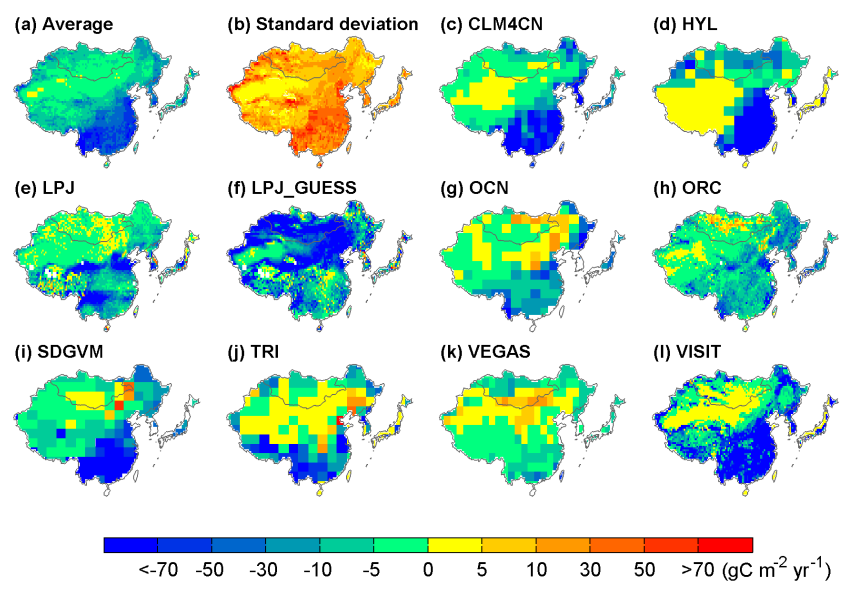

Fig. 5. Ten ecosystem models simulated spatial patterns of net ecosystem carbon balance in response to climate change and rising atmospheric $\mathrm{CO}_{2}$ (Simulation S2) during the period 1990-2009. (a) Average net ecosystem carbon balance from the ten models, (b) standard deviation of the ten model-derived net ecosystem carbon balance, and (c-h) net ecosystem carbon balance estimated by each model. Negative value indicates net carbon sink.

1990 to 2009 (Mao et al., 2012). These two simulations derived by different models further suggest that there is a large uncertainty in the estimation of the nitrogen depositioncaused carbon sink over East Asia. Here, we took the average of these two studies $\left(-0.107 \pm 0.025 \mathrm{Pg} \mathrm{C} \mathrm{yr}^{-1}\right)$ (Fig. 6).

\subsubsection{Land use and land-use change}

Land-use change is one of the important disturbances that alter terrestrial carbon pools and net fluxes at regional and global scales (Houghton, 2003). However, it is extremely challenging to accurately estimate the carbon balance change associated with land-use change because of current lack of information on the amount and spatial pattern of deforestation and biomass and soil C stocks (Houghton, 2007; Piao et al., 2009b). For instance, Houghton et al. (2003) estimated that land-use change in China led to net carbon emission of $0.03 \mathrm{PgC}^{-1}$ during the 1990s, while Jian and Yang (2005) found oppositely that land-use change in China resulted in net carbon accumulation of $-0.03 \mathrm{PgC} \mathrm{yr}^{-1}$ (Jian and Yang, 2005), which is very close to the estimation based on forest area changes from inventory data $\left(-0.02 \mathrm{Pg} \mathrm{C} \mathrm{yr}^{-1}\right.$, Fang et al., 2001) and from the DLEM and TEM models ( $-0.03 \mathrm{Pg} \mathrm{Cyr}^{-1}$, Tian et al., 2011). Based on these results, we estimated that land-use change, dominated by afforestation, caused a net carbon accumulation in East Asia of $0.013 \pm 0.029 \mathrm{Pg} \mathrm{Cyr}^{-1}$ (ranging from a source of $0.03 \mathrm{Pg} \mathrm{Cyr}^{-1}$ to a sink of $-0.03 \mathrm{PgC} \mathrm{yr}^{-1}$ ) (Fig. 6). 


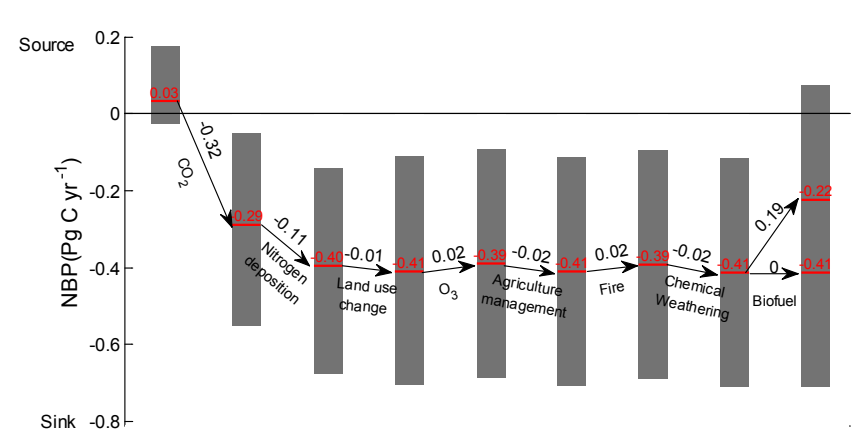

Fig. 6. Different factors' (climate, climate $+\mathrm{CO}_{2}$, nitrogen deposition, land-use change, $\mathrm{O}_{3}$ pollution, agricultural management, fire and biofuels) contributions to the carbon balance of terrestrial ecosystems in East Asia. Negative values indicate net carbon sink. Grey bars show ranges in the estimates by different models or sources. Biofuel emissions are fully accounted for when assuming the harvested carbon stock is not compensated by vegetation regrowth, and they are not accounted for when assuming the harvested carbon stock is fully compensated by vegetation regrowth. Potential interactions among different factors are not considered. The contributions of atmospheric $\mathrm{O}_{3}$ pollution and agriculture management on the carbon balance are estimated over China rather than over the entire East Asia region due to lack of information for other countries (see Sect. 3.2.4).

\subsubsection{Atmospheric ozone pollution and other fluxes}

In addition to these factors (i.e. climate change, rising $\mathrm{CO}_{2}$, nitrogen deposition and land-use change), previous studies have suggested that atmospheric $\mathrm{O}_{3}$ pollution has also caused a decrease in carbon storage in China by $0.02 \mathrm{Pg} \mathrm{C} \mathrm{yr}^{-1}$ (Tian et al., 2011), while intensive agricultural practices and their changes, such as nitrogen fertilization and decreasing removal of crop residues, have been thought to lead to an increase in carbon sequestration by $0.022 \pm 0.004 \mathrm{Pg} \mathrm{C} \mathrm{yr}^{-1}$ (Huang et al., 2010).

Wildfires may also play an important role in the regional carbon balance. Satellite data of burned area incorporated in the CASA terrestrial biosphere model estimated mean annual carbon emission from ecosystem fire in East Asia from 1997 to 2009 of $0.018 \pm 0.010 \mathrm{Pg} \mathrm{Cyr}^{-1}$ (van der Werf et al., 2010). Most of the carbon emission from wildfires occurred in China (56.9\%) and Mongolia (37.5\%), which contain vast areas of dry forests, shrub lands, and grasslands (van der Werf et al., 2010).

In addition, $\mathrm{CO}_{2}$ consumption by chemical weathering of silicates and carbonates is a carbon sink not counted in the modeling. Based on lithological maps, river runoff and river chemistry datasets (Hartmann et al., 2009; Hartmann, 2009), net $\mathrm{CO}_{2}$ consumption by chemical weathering over the considered East Asian territory was estimated to be $0.020 \mathrm{Pg} \mathrm{C} \mathrm{yr}^{-1}$.

Finally, carbon emissions from biofuels, such as woodfuel and agricultural residues, are not taken into account for most of the carbon cycle models. Recently, Wang et al. (2012) estimated the biofuel emissions in China to be about $0.189 \pm 0.010 \mathrm{Pg} \mathrm{Cyr}^{-1}$, a very large flux compared to natural $\mathrm{C}$ sinks. If biofuel harvest is exactly compensated by a vegetation regrowth sink that can not be detected by the inventory, the biofuel emissions should not be included in the carbon balance estimation based on the carbon cycle model approach. Otherwise, if the harvest of biofuel carbon stock is not compensated by vegetation regrowth, the biofuel carbon emissions should be included. Since we do not have information on the biofuel harvests compensated by the vegetation regrowth sink, we consider both situations, resulting in two estimates of carbon balance - either fully considering biofuel emissions or not.

Overall, based on process-based ecosystem models and considering the carbon sinks/sources caused by all these different factors estimated in this and previous studies, we estimate that the carbon balance over East Asia is $-0.224 \pm 0.141 \mathrm{Pg} \mathrm{Cyr}^{-1}$ considering the biofuel emissions, or $-0.413 \pm 0.141 \mathrm{Pg} \mathrm{C} \mathrm{yr}^{-1}$ not considering biofuel emissions (ranging from a carbon source of $0.099 \mathrm{Pg} \mathrm{C} \mathrm{yr}^{-1}$ to a carbon sink of $-0.680 \mathrm{PgC} \mathrm{yr}^{-1}$ ) (Fig. 6, Supplement Table S2).

\subsection{Atmospheric inverse model estimates}

Over the whole East Asia, the average of eight inverse models give a net sink of atmospheric $\mathrm{CO}_{2}$ of $-0.380 \pm 0.497 \mathrm{PgC} \mathrm{yr}^{-1}$, but the eight models do not agree with each other. Six models estimate a net $\mathrm{CO}_{2}$ uptake over East Asia, but two models show a net $\mathrm{CO}_{2}$ source (Table 2). The C13 MATCH model estimated the highest net carbon uptake rate of $-0.997 \mathrm{Pg} \mathrm{Cyr}^{-1}$, while the $\mathrm{C} 13 \mathrm{CCAM}$ model showed the largest net carbon emission of $0.416 \mathrm{Pg} \mathrm{C} \mathrm{yr}^{-1}$ (Fig. 7), indicating that inversion fluxes over East Asia are rather poorly constrained by a regionally scarce atmospheric observation network. If we further consider propagating uncertainty of fossil fuel emissions over East Asia $\left(0.098 \mathrm{Pg} \mathrm{Cyr}^{-1}\right)$, the uncertainty of net $\mathrm{CO}_{2}$ exchange estimated by inverse models increases to $0.507 \mathrm{Pg} \mathrm{C} \mathrm{yr}^{-1}$.

The inverse model-derived net land-atmosphere $\mathrm{CO}_{2}$ exchange is not directly comparable with the carbon sink estimated by the bottom-up approaches. In order to reconcile the two approaches, $\mathrm{CO}_{2}$ fluxes out of and into the atmosphere from food and wood products trade, non- $\mathrm{CO}_{2}$ gas emissions, and the emissions of $\mathrm{C}$ pools not counted in fossil fuel emissions (e.g. peat use) must be considered to adjust the inverse model estimate (Ciais et al., 2008). The emission of $\mathrm{CO}_{2}$ to the atmosphere from consumption of imported (exported) food and wood should be added to (removed from) the regional inverse estimates for making a comparison with bottom-up $\mathrm{C}$ accounting approaches. We estimated the carbon emissions of imported food and wood by analyzing FAO statistics on international trade (FAO, 2010). The imported crop biomass in East Asia was converted into 


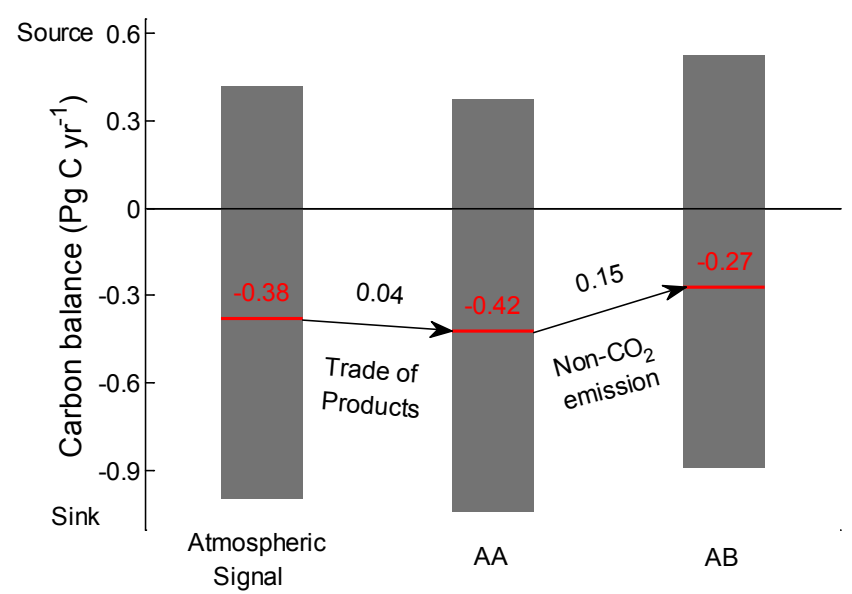

Fig. 7. Atmospheric inversion model estimated carbon balance in East Asia through considering lateral carbon fluxes. The same fossil fuel $\mathrm{CO}_{2}$ emission estimate has been removed from each inversion to obtain the land-atmosphere $\mathrm{CO}_{2}$ flux. The average of seven inverse model estimations (atmospheric signal) is corrected by two lateral fluxes. (1) $\mathrm{CO}_{2}$ emissions due to imported wood and food products $\left(0.04 \mathrm{PgC} \mathrm{yr}^{-1}\right)$ are added to the atmospheric inversion result, resulting in AA; (2) the carbon sink in AA is reduced by carbon fixed by photosynthesis but released to the atmosphere by non$\mathrm{CO}_{2}$ compounds $\left(0.15 \mathrm{PgC} \mathrm{yr}^{-1}\right)$, including $\mathrm{CO}, \mathrm{CH}_{4}$ and volatile organic compounds (VOCs), resulting in $\mathrm{AB}$, which should be comparable to estimates by the inventory- and satellite-based approach. Grey bars show ranges in the estimates by different inverse models.

carbon using a crop-specific conversion factor (Goudriaan et al., 2001), and imported wood was transformed to carbon following the method of Ciais et al. (2008). Thus, we estimated that the imported wood and food consumption was $0.04 \mathrm{Pg} \mathrm{C} \mathrm{yr}^{-1}$ during $1990-2009$. The non- $\mathrm{CO}_{2}$ compounds such as $\mathrm{CO}, \mathrm{CH}_{4}$ and BVOC (biogenic volatile organic compounds) emitted by ecosystems, which were also not captured by atmospheric $\mathrm{CO}_{2}$ observations, should be subtracted from the inverse estimate when assessing the total carbon balance. Using an atmospheric chemistry database (Folberth et al., 2006), we estimated that the biogenic non- $\mathrm{CO}_{2}$ emission was $0.15 \mathrm{Pg} \mathrm{C} \mathrm{yr}^{-1}$. Due to the lack of information, the removal of fossil $\mathrm{C}$ not counted in fossil fuel emissions (e.g. peat use) is not considered in our study. By adjusting the inverse estimates using these lateral fluxes, the top-down approach estimated that the terrestrial ecosystems of East Asia functioned as a net carbon sink of $-0.270 \pm 0.507 \mathrm{Pg} \mathrm{C} \mathrm{yr}^{-1}$ during 1990-2009, with a range from net carbon emission of $0.526 \mathrm{Pg} \mathrm{Cyr}^{-1}$ to net carbon sink of $-0.887 \mathrm{PgC} \mathrm{yr}^{-1}$ (Fig. 7, Supplement Table S2).

\section{Summary}

In summary, based on the average carbon sink from three approaches presented in this study, we estimate that East Asia's terrestrial territory during the 1990s and 2000s were a net carbon sink of -0.224 to $-0.413 \mathrm{Pg} \mathrm{Cyr}^{-1}$ (average of $\left.-0.294 \mathrm{Pg} \mathrm{C} \mathrm{yr}^{-1}\right)$, accounting for 13-27\% of the carbon sink over the Northern Hemisphere (Stephens et al., 2007). During the same period, fossil fuel burning in East Asia produced a cumulated emission of $1.5 \mathrm{Pg} \mathrm{Cyr}^{-1}$ to the atmosphere (IEA, 2011; Fig. 1), suggesting that about 13-27\% of East Asia's $\mathrm{CO}_{2}$ emissions from fossil fuel burning are offset by carbon accumulation in its terrestrial ecosystems.

Although the average carbon sink estimated by three different approaches was found to be comparable, there are still large uncertainties in each approach. For the inventory and satellite data based approach, the largest uncertainty lies in the estimation of soil organic carbon storage change, while for the terrestrial ecosystem modeling approach, carbon balance associated with land-use change and nitrogen deposition was inconsistent among different models. Promoting a regional model intercomparison project for East Asia, like the VEMAP project for the United States, will help constrain the uncertainties associated with process representation and parameters in the models. There are also large variations in the estimated carbon balance among different inverse models. To enable more precise assessments of East Asia's carbon cycle, there is an urgent need to increase the sampling of forest and grassland soils, and to deploy more atmospheric $\mathrm{CO}_{2}$ stations. In order to correct the differences among different approaches, there is also a need to improve data products of lateral fluxes (e.g. non- $\mathrm{CO}_{2}$ emissions and carbon exchange between terrestrial ecosystems and inland waters), particularly in their spatial and temporal resolutions. On the analogy of meteorological re-analyses, such an integration system will allow us to establish a "re-analysis" dataset of the global and regional carbon cycles.

\section{Supplementary material related to this article is available online at: http://www.biogeosciences.net/9/ 3571/2012/bg-9-3571-2012-supplement.pdf.}

Acknowledgements. This study is part of the REgional Carbon Cycle Assessment and Processes (RECCAP), Global Carbon Project. We thank atmospheric inversion modelers for providing atmospheric $\mathrm{CO}_{2}$ inversion results. This study was supported by the National Natural Science Foundation of China (grant 41125004 and 30970511), National Basic Research Program of China (Grant No. 2010CB950601 and Grant No. 2010CB833501), Foundation for Sino-EU research cooperation of Ministry of Science and Technology of China (1003), CARBONES EU FP7 foundation (242316) and Chinese Ministry of Environmental Protection Grant (201209031).

Edited by: J. Canadell 


\section{References}

Akimoto, H.: Global air quality and pollution, Science, 302, 17161719, doi:10.1126/science.1092666, 2003.

Baker, D. F., Law, R. M., Gurney, K. R., Rayner, P., Peylin, P., Denning, A. S., Bousquet, P., Bruhwiler, L., Chen, Y. H., Ciais, P., Fung, I. Y., Heimann, M., John, J., Maki, T., Maksyutov, S., Masarie, K., Prather, M., Pak, B., Taguchi, S., and Zhu, Z.: TransCom 3 inversionintercomparison: Impact of transport model errors on the interannual variability of regionalCO2 fluxes, 1988-2003, Global Biogeochem. Cy., 20, GB1002, doi:10.1029/2004GB002439, 2006.

Cai, W., Guo, X., Chen, A., Dai, M., Zhang, L., Zhai, W., Lohrenz, S. E., Yin, K., Harrison, P. J., and Wang, Y.: A comparative overview of weathering intensity and hco3- flux in the world's major rivers with emphasis on the changjiang, huanghe, zhujiang (pearl) and mississippi rivers, Cont. Shelf. Res., 28, 1538-1549, doi:10.1016/j.csr.2007.10.014, 2008.

Canadell, J. G., Ciais, P., Gurney, K., Le Quéré, C., Piao, S., Raupach, M. R., and Sabine, C. L.: An international effort to quantify regional carbon fluxes, E. O. S., 92, 81-82, 2011.

Carvalhais, N., Reichstein, M., Seixas, J., Collatz, G. J., Pereira, J. S., Berbigier, P., Carrara, A., Granier, A., Montagnani, L., Papale, D., Rambal, S., Sanz, M. J., and Valentini, R.: Implications of the carbon cycle steady state assumption for biogeochemical modeling performance and inverse parameter retrieval, Global Biogeochem. Cy., 22, Gb2007, doi:10.1029/2007gb003033, 2008.

Chevallier, F., Fisher, M., Peylin, P., Serrar, S., Bousquet, P., Bréon, F. M., Chédin, A., and Ciais, P.: Inferring $\mathrm{CO} 2$ sources and sinks from satellite observations: Method and application to TOVS data, J. Geophys. Res., 110, D24309, doi:10.1029/2005jd006390, 2005.

Choi, S. D. and Chang, Y. S.: Factors affecting the distribution of the rate of carbon uptake by forests in South Korea, Environ. Sci. Technol., 38, 484-488, doi:10.1021/es034533u, 2004.

Churkina, G., Trusilova, K., Vetter, M., and Dentener, F.: Contributions of nitrogen deposition and forest regrowth to terrestrial carbon uptake, Carbon Balance Manage., 2, doi:10.1186/17500680-2-5, 2007.

Churkina, G., Zaehle, S., Hughes, J., Viovy, N., Chen, Y., Jung, M., Heumann, B. W., Ramankutty, N., Heimann, M., and Jones, C.: Interactions between nitrogen deposition, land cover conversion, and climate change determine the contemporary carbon balance of Europe, Biogeosciences, 7, 2749-2764, doi:10.5194/bg7-2749-2010, 2010.

Ciais, P., Borges, A. V., Abril, G., Meybeck, M., Folberth, G., Hauglustaine, D., and Janssens, I. A.: The impact of lateral carbon fluxes on the European carbon balance, Biogeosciences, 5, 1259-1271, doi:10.5194/bg-5-1259-2008, 2008.

Ciais, P., Canadell, J. G., Luyssaert, S., Chevallier, F., Shvidenko, A., Poussi, Z., Jonas, M., Peylin, P., King, A. W., Schulze, E. D., Piao, S. L., Rodenbeck, C., Peters, W., and Breon, F. M.: Can we reconcile atmospheric estimates of the Northern terrestrial carbon sink with land-based accounting?, Curr. Opin. Env. Sust., 2, 225-230, doi:10.1016/j.cosust.2010.06.008, 2010.

Crevoisier, C., Sweeney, C., Gloor, M., Sarmiento, J. L., and Tans, P. P.: Regional US carbon sinks from three-dimensional atmospheric $\mathrm{CO}_{2}$ sampling, Proc. Natl. Acad. Sci. USA, 107, 1834818353, doi:10.1073/pnas.0900062107, 2010.
Commission for Integrated Survey of Natural Resources, ChineseAcademy of Sciences, $1: 4,000,000$ Vegetation Map of China, Chinese Map Press, Beijing, 1996.

Cox, P. M.: Description of the TRIFFID dynamic globalvegetation model. Tech. Note 24, Hadley Centre, Met Office, 16 pp., 2001.

DeFries, R. S., Hansen, M., Townshend, J. R. G., and Sohlberg, R.: Global land cover classifications at $8 \mathrm{~km}$ spatial resolution: the use of training data derived from Landsat imagery in decision tree classifiers, Int. J. Remote Sens., 19, 3141-3168, doi:10.1080/014311698214235, 1998.

Dentener, F., Stevenson, D., Ellingsen, K., van Noije, T., Schultz, M., Amann, M., Atherton, C., Bell, N., Bergmann, D., Bey, I., Bouwman, L., Butler, T., Cofala, J., Collins, B., Drevet, J., Doherty, R., Eickhout, B., Eskes, H., Fiore, A., Gauss, M., Hauglustaine, D., Horowitz, L., Isaksen, I. S. A., Josse, B., Lawrence, M., Krol, M., Lamarque, J. F., Montanaro, V., Muller, J. F., Peuch, V. H., Pitari, G., Pyle, J., Rast, S., Rodriguez, J., Sanderson, M., Savage, N. H., Shindell, D., Strahan, S., Szopa, S., Sudo, K., Van Dingenen, R., Wild, O., and Zeng, G.: The global atmospheric environment for the next generation, Environ. Sci. Technol., 40, 3586-3594, doi:10.1021/es0523845, 2006.

Dufour, G., Eremenko, M., Orphal, J., and Flaud, J.-M.: IASI observations of seasonal and day-to-day variations of tropospheric ozone over three highly populated areas of China: Beijing, Shanghai, and Hong Kong, Atmos. Chem. Phys., 10, 37873801, doi:10.5194/acp-10-3787-2010, 2010.

Enting, I. G., Trudinger, C. M., and Francey, R. J.: A Synthesisinversion of the concentration and DELTA-C-13 of atmospheric $\mathrm{CO}_{2}$, Tellus B., 47, 35-52, doi:10.1034/j.1600-0889.47.issue1.5.x, 1995.

Fan, J., Zhong, H., Harris, W., Yu, G., Wang, S., Hu, Z., and Yue, Y.: Carbon storage in the grasslands of China based on field measurements of above- and below-ground biomass, Clim. Change, 86, 375-396, doi:10.1007/s10584-007-9316-6, 2008.

Fang, J. Y. and Chen, A. P.: Dynamic forest biomass carbon pools in China and their significance, Acta Bot. Sin., 43, 967-973, 2001.

Fang, J. Y., Oikawa, T., Kato, T., Mo, W. H., and Wang, Z. H.: Biomass carbon accumulation by Japan's forests from1947 to 1995, Global Biogeochem. Cy., 19, GB2004, 1-10, doi:10.1029/2004GB002253, 2005.

FAO, Food and Agriculture Organization: Global Forest Resources Assessment, FAO, Rome, Italy, 2010.

Folberth, G. A., Hauglustaine, D. A., Lathière, J., and Brocheton, F.: Interactive chemistry in the Laboratoire de Météorologie Dynamique general circulation model: model description and impact analysis of biogenic hydrocarbons on tropospheric chemistry, Atmos. Chem. Phys., 6, 2273-2319, doi:10.5194/acp-62273-2006, 2006.

Friedlingstein, P., Cox, P., Betts, R., Bopp, L., Von Bloh, W., Brovkin, V., Cadule, P., Doney, S., Eby, M., Fung, I., Bala, G., John, J., Jones, C., Joos, F., Kato, T., Kawamiya, M., Knorr, W., Lindsay, K., Matthews, H. D., Raddatz, T., Rayner, P., Reick, C., Roeckner, E., Schnitzler, K. G., Schnur, R., Strassmann, K., Weaver, A. J., Yoshikawa, C., and Zeng, N.: Climate-carbon cycle feedback analysis: Results from the C(4)MIP model intercomparison, J. Climate, 19, 3337-3353, doi:10.1175/jcli3800.1, 2006.

Fu, G. B., Chen, S. L., Liu, C. M., and Shepard, D.: Hydro-climatic trends of the Yellow River basin 
for the last 50 years, Clim. Change, 65, 149-178, doi:10.1023/B:CLIM.0000037491.95395.bb, 2004.

Galloway, J. N., Dentener, F. J., Capone, D. G., Boyer, E. W., Howarth, R. W., Seitzinger, S. P., Asner, G. P., Cleveland, C. C., Green, P. A., Holland, E. A., Karl, D. M., Michaels, A. F., Porter, J. H., Townsend, A. R., and Vorosmarty, C. J.: Nitrogen cycles: past, present, and future, Biogeochemistry, 70, 153-226, doi:10.1007/s10533-004-0370-0, 2004.

Gregg, J. S., Andres, R. J., and Marland, G.: China: Emissions pattern of the world leader in $\mathrm{CO}_{2}$ emissions from fossil fuel consumption and cement production, Geophys. Res. Lett., 35, L08806, doi:10.1029/2007g1032887, 2008.

Goudriaan, J., Groot, J. R., and Uithol, P. W. J.: Productivity ofAgro-ecosystems, in: Terrestrial Global Productivity, Academic Press, 301-303, 2001.

Gurney, K., Law, R. M., Denning, A. S., and Rayner, P. J.: Towards more robustestimates of $\mathrm{CO}_{2}$ fluxes: control results from theTransCom3 inversion intercomparison, Nature, 415, 626-630, 2002.

Gurney, K. R., Chen, Y. H., Maki, T., Kawa, S. R., Andrews, A., and Zhu, Z. X.: Sensitivity of atmospheric $\mathrm{CO}_{2}$ inversions to seasonal and interannual variations in fossil fuel emissions, J. Geophys. Res.-Atmos., 110, doi:10.1029/2004jd005373, 2005.

Gurney, A., Ahammad, H., and Ford, M.: The economics of greenhouse gas mitigation: Insights from illustrative global abatement scenarios modelling, Energy Econ., 31, S174-S186, doi:10.1016/j.eneco.2009.08.016, 2009.

Hartmann, J., Jansen, N., Dürr, H. H., Kempe, S., and Köhler, P.: Global $\mathrm{CO}_{2}$-consumption by chemical weathering: What is the contribution of highly active weathering regions?, Global Planet. Change, 69, 185-194, doi:10.1016/j.gloplacha.2009.07.007, 2009.

Hartmann, J.: Bicarbonate-fluxes and CO2-consumption by chemical weathering on the Japanese Archipelago - Application of a multi-lithological model framework, Chem. Geol., 65, 237-271. doi:10.1016/j.chemgeo.2009.03.024, 2009.

Houghton, R. A.: Revised estimates of the annual net flux of carbon to the atmosphere from changes in land use and land management 1850-2000, Tellus B., 55, 378-390, doi:10.1034/j.16000889.2003.01450.x, 2003.

Houghton, R. A.: Balancing the global carbon budget, in: Annual Review of Earth and Planetary Sciences, Annu. Rev. Earth Pl. Sc., 313-347, 2007.

Huang, Y. and Sun, W.: Changes in topsoil organic carbon of croplands in mainland China over the last two decades, Chinese Sci. Bull., 51, 1785-1803, doi:10.1007/s11434-006-2056-6, 2006.

Huang, Y., Sun, W., Zhang, W., and Yu, Y.: Changes in soil organic carbon of terrestrial ecosystems in China: A mini-review, Science China-Life Sciences, 53, 766-775, doi:10.1007/s11427010-4022-4, 2010.

Ichii, K., Suzuki, T., Kato, T., Ito, A., Hajima, T., Ueyama, M., Sasai, T., Hirata, R., Saigusa, N., Ohtani, Y., and Takagi, K.: Multi-model analysis of terrestrial carbon cycles in Japan: limitations and implications of model calibration using eddy flux observations, Biogeosciences, 7, 2061-2080, doi:10.5194/bg-72061-2010, 2010.

IGCAS, Institute of Geography, ChineseAcademy of Sciences: Digitized vegetation map of China, Beijing, National Laboratory for GIS and Remote Sensing, 1996.
International Energy Agency (IEA): CO Emissions from Fuel Combustion 2011 Edition, IEA, Paris, 134 pp., 2011.

Ito, A.: The regional carbon budget of East Asia simulated with a terrestrial ecosystem model and validated using AsiaFlux data, Agric. For. Meteorol., 148, 738-747, doi:10.1016/j.agrformet.2007.12.007, 2008.

Janssens, I. A., Freibauer, A., Ciais, P., Smith, P., Nabuurs, G. J., Folberth, G., Schlamadinger, B., Hutjes, R. W. A., Ceulemans, R., Schulze, E. D., Valentini, R., and Dolman, A. J.: Europe's terrestrial biosphere absorbs 7 to $12 \%$ of European anthropogenic $\mathrm{CO}_{2}$ emissions, Science, 300, 1538-1542, doi:10.1126/science.1083592, 2003.

Janssens, I. A., Dieleman, W., Luyssaert, S., Subke, J. A., Reichstein, M., Ceulemans, R., Ciais, P., Dolman, A. J., Grace, J., Matteucci, G., Papale, D., Piao, S. L., Schulze, E. D., Tang, J., and Law, B. E.: Reduction of forest soil respiration in response to nitrogen deposition, Nat. Geosci., 3, 315-322, doi:10.1038/ngeo844, 2010.

Jeong, S. J., Ho, C. H., Brown, M. E., Kug, J. S., and Piao, S. L.: Browning in desert boundaries in Asia in recent decades, J. Geophys. Res.-Atmos., 116, doi:10.1029/2010jd014633, 2011.

Keeling, C. D. and Whorf, T. P.: Atmospheric $\mathrm{CO}_{2}$ Records from Sites in the SIO Air Sampling Network, in Trends: a Compendium of Data on Global Change, Carbon Dioxide Inf. Anal. Cent. Oak Ridge Natl. Lab., Oak Ridge, Tenn, 2005.

Kohlmaier, G., Kohlmaier, L., Fries, E., and Jaeschke, W.: Application of the stock change and the production approach to Harvested Wood Products in the EU-15 countries: a comparative analysis, Eur. J. For. Res., 126, 209-223, doi:10.1007/s10342006-0130-x, 2007.

Krinner, G., Viovy, N., de Noblet-Ducoudre, N., Ogee, J., Polcher, J., Friedlingstein, P., Ciais, P., Sitch, S., and Prentice, I. C.: A dynamic global vegetation model for studies of the coupled atmosphere-biosphere system, Global Biogeochem. Cy., 19, GB1015, doi:10.1029/2003gb002199, 2005.

Law, R. M., Kowalczyk, E. A., and Wang, Y. P.: Using atmospheric $\mathrm{CO} 2$ data to assess a simplified carbon-climate simulation for the 20th century, Tellus B., 58, 427-437, doi:10.1111/j.16000889.2006.00198.x, 2006.

Lawrence, D., Oleson, K. W., Flanner, M. G., Thorton, P. E., Swenson, S. C., Lawrence, P. J., Zeng, X. B., Yang, Z. L., Levis, S., Skaguchi, K., Bonan, G. B., and Slater, A. G.: Parameterization improvements and functional and structural advances in version 4 of the Community Land Model, J. Adv. Model. Earth Syst., 3, 27 pp., 2011.

Lee, S., Akimoto, H., Nakane, H., Kurnosenko, S., and Kinjo, Y.: Lower tropospheric ozone trend observed in 1989-1997 at Okinawa, Japan, Geophys. Res. Lett., 25, 1637-1640, doi:10.1029/98g101224, 1998.

Levy, P. E., Cannell, M. G. R., and Friend, A. D.: Modelling the impact of future changes in climate, $\mathrm{CO}_{2}$ concentration and land use on natural ecosystems and the terrestrial carbon sink, Global Environ, Change-Human Policy Dimens., 14, 21-30, doi:10.1016/j.gloenvcha.2003.10.005, 2004.

Lin, J. C., Pejam, M. R., Chan, E., Wofsy, S. C., Gottlieb, E. W., Margolis, H. A., and McCaughey, J. H.: Attributing uncertainties in simulated biospheric carbon fluxes to different error sources, Global Biogeochem. Cy., 25, Gb2018, doi:10.1029/2010gb003884, 2011. 
Lu, C. Q. and Tian, H. Q.: Spatial and temporal patterns of nitrogen deposition in China: Synthesis of observational data, J. Geophys. Res.-Atmos., 112, D22S05, doi:10.1029/2006jd007990, 2007.

Lu, F., Wang, X., Han, B., Ouyang, Z., Duan, X., Zheng, H., and Miao, H.: Soil carbon sequestrations by nitrogen fertilizer application, straw return and no-tillage in China's cropland, Global Change Biol., 15, 281-305, doi:10.1111/j.13652486.2008.01743.x, 2009.

Ludwig, W., Probst, J. L., and Kempe, S.: Predicting the oceanic input of organic carbon by continental erosion, Global Biogeochem. Cy., 10, 23-41, 1996.

Luyssaert, S., Ciais, P., Piao, S. L., Schulze, E. D., Jung, M., Zaehle, S., Schelhaas, M. J., Reichstein, M., Churkina, G., Papale, D., Abril, G., Beer, C., Grace, J., Loustau, D., Matteucci, G., Magnani, F., Nabuurs, G. J., Verbeeck, H., Sulkava, M., van der Werf, G. R., Janssens, I. A., and Team, C.-I. S.: The European carbon balance. Part 3: forests, Global Change Biol., 16, 14291450, doi:10.1111/j.1365-2486.2009.02056.x, 2010.

Mao, J. F., Shi, X. Y., Thornton, P. E., Piao S. L., and Wang, X. H.: Causes of spring vegetation growth trends in the northern midhigh latitudes from 1982 to 2004, Environ. Res. Lett., 7, 014010, doi:10.1088/1748-9326/7/1/014010, 2012.

Maksyutov, S., Patra, P. K., Onishi, R., Saeki, T., and Nakazawa, T.: NIES/FRCGC global atmospheric tracer transport model: description,validation, and surface sources and sinks inversion, J. Earth Simulator, 9, 3-18, 2008.

Mayorga, E., Seitzinger, S. P., Harrison, J. A., Dumont, E., Beusen, A., Bouwman, A. F., Fekete, B. M., Kroeze, C., and Van Drecht, G.: Global Nutrient Export from WaterSheds 2 (NEWS 2): Model development and implementation, Environ. Modell. Softw., 25, 837-853, doi:10.1016/j.envsoft.2010.01.007, 2010.

Meybeck, M., Durr, H. H., and Vorosmarty, C. J.: Global coastal segmentation and its river catchment contributors: A new look at land-ocean linkage, Global Biogeochem. Cy., 20, GB1S90, doi:10.1029/2005gb002540, 2006.

Mitchell, T. D. and Jones, P. D.: An improved method of constructing a database of monthly climate observations and associated high-resolution grids, Int. J. Climatol., 25, 693-712, doi:10.1002/joc.1181, 2005.

Mitchell, S., Beven, K., and Freer, J.: Multiple sources of predictive uncertainty in modeled estimates of net ecosystem $\mathrm{CO}_{2}$ exchange, Ecol. Model, 220, 3259-3270, doi:10.1016/j.ecolmodel.2009.08.021, 2009.

Morales, P., Sykes, M. T., Prentice, I. C., Smith, P., Smith, B., Bugmann, H., Zierl, B., Friedlingstein, P., Viovy, N., Sabate, S., Sanchez, A., Pla, E., Gracia, C. A., Sitch, S., Arneth, A., and Ogee, J.: Comparing and evaluating process-based ecosystem model predictions of carbon and water fluxes in major European forest biomes, Global Change Biol., 11, 2211-2233, doi:10.1111/j.1365-2486.2005.01036.x, 2005.

Oleson, K. W., Bonan, G. B., and Feddema, J.: Effects of white roofs on urban temperature in a global climate model, Geophys. Res. Lett., 37, L03701, doi:10.1029/2009g1042194, 2010.

Olivier, J. G. J. and Berdowski, J. J. M.: Global emissions sources and sinks, in: The Climate System, edited by: Berdowski, J., Guicherit, R., and Heij, B. J., A.A. Balkema Publishers/Swets \& Zeitlinger Publishers, Lisse, The Netherlands, 33-78, 2001.

Oltmans, S. J., Lefohn, A. S., Scheel, H. E., Harris, J. M., Levy, H., Galbally, I. E., Brunke, E. G., Meyer, C. P., Lathrop, J. A.,
Johnson, B. J., Shadwick, D. S., Cuevas, E., Schmidlin, F. J., Tarasick, D. W., Claude, H., Kerr, J. B., Uchino, O., and Mohnen, V.: Trends of ozone in the troposphere, Geophys. Res.Lett., 25, 139-142, doi:10.1029/97gl03505, 1998.

Pacala, S. W., Hurtt, G. C., Baker, D., Peylin, P., Houghton, R. A., Birdsey, R. A., Heath, L., Sundquist, E. T., Stallard, R. F., Ciais, P., Moorcroft, P., Caspersen, J. P., Shevliakova, E., Moore, B., Kohlmaier, G., Holland, E., Gloor, M., Harmon, M. E., Fan, S. M., Sarmiento, J. L., Goodale, C. L., Schimel, D., and Field, C. B.: Consistent land- and atmosphere-based US carbon sink estimates, Science, 292, 2316-2320, doi:10.1126/science.1057320, 2001.

Pan, Y. D., Luo, T. X., Birdsey, R., Hom, J., and Melillo, J.: New estimates of carbon storage and sequestration in China's forests: Effects of age-class and method on inventory-based carbon estimation, Climatic Change, 67, 211-236, doi:10.1007/s10584004-2799-5, 2004.

Pan, G., Xu, X., Smith, P., Pan, W., and Lal, R.: An increase in topsoil SOC stock of China's croplands between 1985 and 2006 revealed by soil monitoring, Agr. Ecosyst. Environ., 136, 133138, doi:10.1016/j.agee.2009.12.011, 2010.

Pan, Y. D., Birdsey, R. A., Fang, J. Y., Houghton, R., Kauppi, P. E., Kurz, W. A., Phillips, O. L., Shvidenko, A., Lewis, S. L., Canadell, J. G., Ciais, P., Jackson, R. B., Pacala, S. W., McGuire, A. D., Piao, S. L., Rautiainen, A., Sitch, S., and Hayes, D.: A Large and Persistent Carbon Sink in the World's Forests, Science, 333, 988-993, doi:10.1126/science.1201609, 2011.

Park, H. S. and Sohn, B. J.: Recent trends in changes of vegetation over East Asia coupled with temperature and rainfall variations, J. Geophys. Res.-Atmos., 115, doi:10.1029/2009jd012752, 2010.

Peng, S. S., Chen, A. P., Xu, L., Cao, C. X., Fang, J. Y., Myneni, R. B., Pinzon, J. E., Tucker, C. J., and Piao, S. L.: Recent Change of Vegetation Growth Trend in China, Environ. Res. Lett., 6, doi:10.1088/1748-9326/6/4/044027, 2011.

Peters, W., Jacobson, A. R., Sweeney, C., Andrews, A. E., Conway, T. J., Masarie, K., Miller, J. B., Bruhwiler, L. M. P., Petron, G., Hirsch, A. I., Worthy, D. E. J., van der Werf, G. R., Randerson, J. T., Wennberg, P. O., Krol, M. C., and Tans, P. P.: An atmospheric perspective on North American carbon dioxide exchange: CarbonTracker, Proc. Natl. Acad. Sci. USA, 104, 18925-18930, doi:10.1073/pnas.0708986104, 2007.

Peylin, P., Rayner, P. J., Bousquet, P., Carouge, C., Hourdin, F., Heinrich, P., Ciais, P., and contributors, A.: Daily $\mathrm{CO}_{2}$ flux estimates over Europe from continuous atmospheric measurements: 1, inverse methodology, Atmos. Chem. Phys., 5, 3173-3186, 2005 , http://www.atmos-chem-phys.net/5/3173/2005/.

Peylin, P., Law, R., Gurney, K., Zhang, X. Poussi, Z. and model participants: Atmospheric Inversion results, available at: http://www.globalcarbonproject.org/global/pdf/Atmospheric_ Inversions.pdf, last access: December 2011.

Phillips, D. L., Brown, S. L., Schroeder, P. E., and Birdsey, R. A.: Toward error analysis of large-scale forest carbon budgets, Global Ecol. Biogeogr., 9, 305-313, doi:10.1046/j.13652699.2000.00197.x, 2000.

Piao, S. L., Fang, J. Y., Ji, W., Guo, Q. H., Ke, J. H., and Tao, S.: Variation in a satellite-based vegetation index in relation to climate in China, J. Veg. Sci., 15, 219-226, 2004. 
Piao, S. L., Fang, J. Y., Zhou, L. M., Tan, K., and Tao, S.: Changes in biomass carbon stocks in China's grasslands between 1982 and 1999, Global Biogeochem. Cy., 21, doi:10.1029/2005gb002634, 2007.

Piao, S. L., Fang, J. Y., Ciais, P., Peylin, P., Huang, Y., Sitch, S., and Wang, T.: The carbon balance of terrestrial ecosystems in China, Nature, 458, 1009-U1082, doi:10.1038/nature07944, 2009a.

Piao, S. L., Ciais, P., Friedlingstein, P., Noblet-Ducoudré, N., Cadule, P., Viovy, N., and Wang, T.: Spatio-temporal patterns of terrestrial carbon cycle during the 20th century, Global Biogeochem. Cy., 23, GB4026, doi:10.1029/2008GB003339, 2009 b.

Piao, S. L., Ciais, P., Huang, Y., Shen, Z. H., Peng, S. S., Li, J. S., Zhou, L. P., Liu, H. Y., Ma, Y. C., Ding, Y. H., Friedlingstein, P., Liu, C. Z., Tan, K., Yu, Y. Q., Zhang, T. Y., and Fang, J. Y.: The impacts of climate change on water resources and agriculture in China, Nature, 467, 43-51, doi:10.1038/nature09364, 2010.

Piao, S. L., Ciais, P., Lomas, M., Beer, C., Liu, H. Y., Fang, J. Y., Friedlingstein, P., Huang, Y., Muraoka, H., Son, Y. H., and Woodward, I.: Contribution of climate change and rising $\mathrm{CO}_{2}$ to terrestrial carbon balance in East Asia: A multi-model analysis, Global Planet. Change, 75, 133-142, doi:10.1016/j.gloplacha.2010.10.014, 2011a.

Piao, S. L., Wang, X. H., Ciais, P., Zhu, B., Wang, T., and Liu J.: Change in satellite derived vegetation growth trend in temperate and boreal Eurasia from 1982 to 2006, Global Change Biol., 17, 3228-3239, doi: 10.1111/j.1365-2486.2011.02419.x, 2011b.

Pregitzer, K. S., Burton, A. J., Zak, D. R., and Talhelm, A. F.: Simulated chronic nitrogen deposition increases carbon storage in Northern Temperate forests, Global Change Biol., 14, 142-153, doi:10.1111/j.1365-2486.2007.01465.x, 2008.

Ramankutty, N., Evan, A. T., Monfreda, C., and Foley, J. A.: Farming the planet: 1. Geographic distribution of global agricultural lands in the year 2000, Global Biogeochem. Cy., 22, Gb1003, doi:10.1029/2007gb002952, 2008.

Rasch, P. J., Mahowald, N. M., and Eaton, B. E.: Representations of transport, convection, and the hydrologic cycle in chemical transport models: Implications for the modeling of shortlived and soluble species, J. Geophys. Res, 102, 28127-28138, doi:10.1029/97jd02087, 1997.

Raupach, M. R., Marland, G., Ciais, P., Le Quere, C., Canadell, J. G., Klepper, G., and Field, C. B.: Global and regional drivers of accelerating $\mathrm{CO}_{2}$ emissions, Proc. Natl. Acad. Sci. USA, 104, 10288-10293, doi:10.1073/pnas.0700609104, 2007.

Richter, A., Burrows, J. P., Nuss, H., Granier, C., and Niemeier, U.: Increase in tropospheric nitrogen dioxide over China observed from space, Nature, 437, 129-132, doi:10.1038/nature04092, 2005.

Rödenbeck, C., Houweling, S., Gloor, M., and Heimann, M.: $\mathrm{CO}_{2}$ flux history 1982-2001 inferred from atmospheric data using a global inversion of atmospheric transport, Atmos. Chem. Phys., 3, 1919-1964, doi:10.5194/acp-3-1919-2003, 2003.

Santaren, D., Peylin, P., Viovy, N., and Ciais, P.: Optimizing a process-based ecosystem model with eddy-covariance flux measurements: A pine forest in southern France, Global Biogeochem. Cy., 21, doi:10.1029/2006gb002834, 2007.

Satoh, M., Matsuno, T., Tomita, H., Miura, H., Nasuno, T., and Iga, S.: Nonhydrostatic icosahedral atmospheric model (NICAM) for global cloud resolving simulations, J. Comput. Phys., 227, 34863514, doi:10.1016/j.jcp.2007.02.006, 2008.
Scurlock, J. M. O. and Hall, D. O.: The global carbon sink: a grassland perspective, Global Change Biol., 4, 229-233, doi:10.1046/j.1365-2486.1998.00151.x, 1998.

Shen, W. X.: Property rights and reform of forest economic system, Forest Econ. Issues, 5, 15-19, 1999.

Sitch, S., Cox, P. M., Collins, W. J., and Huntingford, C.: Indirect radiative forcing of climate change through ozone effects on the land-carbon sink, Nature, 448, 791-U794, doi:10.1038/nature06059, 2007.

Smith, B., Prentice, I. C., and Sykes, M. T.: Representation of vegetation dynamics in the modelling of terrestrial ecosystems: comparing two contrasting approaches within European climate space, Global Ecol. Biogeogr., 10, 621-637, doi:10.1046/j.1466822X.2001.t01-1-00256.x, 2001.

Sitch, S., Smith, B., Prentice, I. C., Arneth, A., Bondeau, A., Cramer, W., Kaplan, J. O., Levis, S., Lucht, W., Sykes, M. T., Thonicke, K., and Venevsky, S.: Evaluation of ecosystem dynamics, plant geography and terrestrial carbon cycling in the LPJ dynamic global vegetation model, Global Change Biol., 9, 161185, doi:10.1046/j.1365-2486.2003.00569.x, 2003.

Sitch, S., Huntingford, C., Gedney, N., Levy, P. E., Lomas, M., Piao, S. L., Betts, R., Ciais, P., Cox, P., Friedlingstein, P., Jones, C. D., Prentice, I. C., and Woodward, F. I.: Evaluation of the terrestrial carbon cycle, future plant geography and climate-carbon cycle feedbacks using five Dynamic Global Vegetation Models (DGVMs), Global Change Biol., 14, 2015-2039, doi:10.1111/j.1365-2486.2008.01626.x, 2008.

Stephens, B. B., Gurney, K. R., Tans, P. P., Sweeney, C., Peters, W., Bruhwiler, L., Ciais, P., Ramonet, M., Bousquet, P., Nakazawa, T., Aoki, S., Machida, T., Inoue, G., Vinnichenko, N., Lloyd, J., Jordan, A., Heimann, M., Shibistova, O., Langenfelds, R. L., Steele, L. P., Francey, R. J., and Denning, A. S.: Weak northern and strong tropical land carbon uptake from vertical profiles of atmospheric $\mathrm{CO}_{2}$, Science, 316, 1732-1735, doi:10.1126/science.1137004, 2007.

Sun, S. H.: Urban expansion in contemporary China: What can we learn from a small town?, Land Use Policy, 27, 780-787, doi:10.1016/j.landusepol.2009.10.010, 2010a.

Sun, W., Huang, Y., Zhang, W., and Yu, Y.: Carbon sequestration and its potential in agricultural soils of China, Global Biogeochem. Cy., 24, GB3001, doi:10.1029/2009gb003484, $2010 \mathrm{~b}$.

Taguchi, S.: A three-dimensional model of atmospheric CO2 transport based on analyzed winds: Model description and simulation results for TRANSCOM, J. Geophys. Res., 101, 15099-15109, doi:10.1029/96jd00504, 1996.

Tan, K., Ciais, P., Piao, S., Wu, X., Tang, Y., Vuichard, N., Liang, S., and Fang, J.: Application of the orchidee global vegetation model to evaluate biomass and soil carbon stocks of Qinghai-Tibetan grasslands, Global Biogeochem. Cy., 24, GB1013, doi:10.1029/2009gb003530, 2010.

Tao, F. and Zhang, Z.: Dynamic responses of terrestrial ecosystems structure and function to climate change in china, J. Geophys. Res., 115, G03003, doi:10.1029/2009jg001062, 2010.

Tian, H. Q., Melillo, J., Lu, C. Q., Kicklighter, D., Liu, M. L., Ren, W., Xu, X. F., Chen, G. S., Zhang, C., Pan, S. F., Liu, J. Y., and Running, S.: China's terrestrial carbon balance: Contributions from multiple global change factors, Global Biogeochem. Cy., 25, GB1007, doi:10.1029/2010gb003838, 2011. 
Tranvik, L. J., Downing, J. A., Cotner, J. B., Loiselle, S. A., Striegl, R. G., Ballatore, T. J., Dillon, P., Finlay, K., Fortino, K., Knoll, L. B., Kortelainen, P. L., Kutser, T., Larsen, S., Laurion, I., Leech, D. M., McCallister, S. L., McKnight, D. M., Melack, J. M., Overholt, E., Porter, J. A., Prairie, Y., Renwick, W. H., Roland, F., Sherman, B. S., Schindler, D. W., Sobek, S., Tremblay, A., Vanni, M. J., Verschoor, A. M., von Wachenfeldt, E., and Weyhenmeyer, G. A.: Lakes and reservoirs as regulators of carbon cycling and climate, Limnol. Oceanogr., 54, 2298-2314, doi:10.4319/lo.2009.54.6_part_2.2298, 2009.

Tucker, C. J., Pinzon, J. E., Brown, M. E., Slayback, D. A., Pak, E. W., Mahoney, R., Vermote, E. F., and El Saleous, N.: An extended AVHRR 8-km NDVI dataset compatible with MODIS and SPOT vegetation NDVI data, Int. J. Remote Sens., 26, 44854498, doi:10.1080/01431160500168686, 2005.

UN: Population Division, World population prospects: the 2008 revision, UN, United Nations, New York, 2009.

van der Werf, G. R., Randerson, J. T., Giglio, L., Collatz, G. J., Mu, M., Kasibhatla, P. S., Morton, D. C., DeFries, R. S., Jin, Y., and van Leeuwen, T. T.: Global fire emissions and the contribution of deforestation, savanna, forest, agricultural, and peat fires (19972009), Atmos. Chem. Phys., 10, 11707-11735, doi:10.5194/acp10-11707-2010, 2010.

Wang, R., Tao, S., Ciais, P., Shen, H. Z., Huang, Y., Chen, H., Shen, G. F., Wang, B., Li, W., Zhang, Y. Y., Lu, Y., Zhu, D., Chen, Y. C., Liu, X. P., Wang, W. T., Wang, X. L., Liu, W. X., Li, B. G., and Piao, S. L.: High resolution mapping of combustion processes and implications for $\mathrm{CO}_{2}$ emissions, Atmos. Chem. Phys. Discuss., 12, 21211-21239, doi:10.5194/acpd-12-212112012, 2012.

Wang, X., Piao, S., Ciais, P., Li, J., Friedlingstein, P., Koven, C., and Chen, A.: Spring temperature change and its implication in the change of vegetation growth in North America from 1982 to 2006, Proc. Natl. Acad. Sci. USA, 108, 1240-1245, doi:10.1073/pnas.1014425108, 2011.
Woodward, F. I. and Lomas, M. R.: Vegetation dynamics - simulating responses to climatic change, Biol. Rev., 79, 643-670, doi:10.1017/s1464793103006419, 2004.

Woodward, F. I., Smith, T. M., and Emanuel, W. R.: A global land primary productivity and phytogeography model, Global Biogeochem. Cy., 9, 471-490, doi:10.1029/95gb02432, 1995.

Wu, Z. Y.: China vegetation, Science Press., Beijing, (in Chinese), 1980.

Yu, Y., Guo, Z., Wu, H., Kahmann, J. A., and Oldfield, F.: Spatial changes in soil organic carbon density and storage of cultivated soils in China from 1980 to 2000, Global Biogeochem. Cy., 23, doi:10.1029/2008gb003428, 2009.

World Bank: Global Economic Prospects, World Bank, Washington D. C., 141-171, 2009.

Zaehle, S., and Friend, A. D.: Carbon and nitrogen cycle dynamics in the O-CN land surface model: 1. Model description, site-scale evaluation, and sensitivity to parameter estimates, Global Biogeochem. Cy., 24, GB1005, doi:10.1029/2009gb003521, 2010.

Zeng, N.: Glacial-interglacial atmospheric $\mathrm{CO}_{2}$ change - The glacial burial hypothesis, Adv. Atmos. Sci., 20, 677-693, doi:10.1007/bf02915395, 2003.

Zeng, N., Mariotti, A., and Wetzel, P.: Terrestrial mechanisms of interannual $\mathrm{CO}_{2}$ variability, Global Biogeochem. Cy., 19, GB1016, doi:10.1029/2004gb002273, 2005.

Zhao, Y., Ciais, P., Peylin, P., Viovy, N., Longdoz, B., Bonnefond, J. M., Rambal, S., Klumpp, K., Olioso, A., Cellier, P., Maignan, F., Eglin, T., and Calvet, J. C.: How errors on meteorological variables impact simulated ecosystem fluxes: a case study for six French sites, Biogeosciences, 9, 2537-2564, doi:10.5194/bg-92537-2012, 2012. 